\title{
Parametrisation of the orographic enhancement of precipitation and deposition in a long-term, long-range transport model
}

\author{
D. S. Lee ${ }^{1}$, R. D. Kingdon ${ }^{1}$, J. A. Garland ${ }^{2}$, B. M. R. Jones ${ }^{3}$ \\ ${ }^{1}$ Defence Evaluation and Research Agency, Propulsion and Performance Department, Pyestock, Farnborough, \\ Hampshire GU14 0LS, United Kingdom \\ 2 Wantage, Oxfordshire, United Kingdom \\ ${ }^{3}$ AEA Technology Environment, Culham Laboratory, Abingdon, Oxfordshire OX14 3DB, United Kingdom
}

Received: 8 November 1999 / Revised: 16 June 2000 / Accepted: 19 June 2000

\begin{abstract}
Orographic enhancement of wet deposition arising from the 'seeder-feeder' effect is, by necessity, highly parametrised in long-range transport models of acid deposition that are long-term (i.e. annual average) and spatially resolved at tens of kilometres. Here, we describe a mechanistic approach to the incorporation of these mechanisms into such a model. The model formulation required the following: precipitation rate by direction and quantification of the fractions that are orographic and non-orographic; treatment of the fast oxidation of sulfur dioxide in clouds; the directionality of the seeder-feeder process; and a quantitative basis for increasing wet deposition factors to account for the seeder-feeder process. The directionality of non-orographic precipitation was determined from meteorological data at 47 sites across the UK. Orographic precipitation varies on a much finer scale than can be interpolated from measurements, and thus a modelling approach was adopted. The directionality of the seederfeeder effect was taken from measurements. The enhancement factor of the orographic component of precipitation, assumed to represent feeder-rain, was determined from a review of measurements. Fast oxidation of sulfur dioxide is an observed phenomenon in cap-cloud, but limited in duration. An adjustment was made to the sulfur dioxide oxidation rate in the model in locations where cap-cloud was assumed to be present. The results from the model were compared with UK deposition budgets and enhanced wet deposition maps. The revised parametrisation underestimated the UK wet deposition budgets of oxidised $\mathrm{N}$ and $\mathrm{S}$, but spatial patterns of deposition were improved for much of the UK. It was concluded that this was a satisfactory outcome given the constraints of the statistical approach of weighting of deposition at receptors utilising straight line trajectories. The sensitivity of the model to directional constraints of seeder-feeder enhancement was tested and it was concluded that a fairly narrow
\end{abstract}

Correspondence to: D. S. Lee

e-mail: dslee@dera.gov.uk constraint resulted in similar estimations to a broader one, and the broader constraint was thus adopted as frontal conditions which result in the process arrive from a fairly broad band of directions. When enhancement was allowed to occur from all directions, UK wet deposition of oxidised $\mathrm{N}$ and $\mathrm{S}$ was increased by $10 \%$. The sensitivity to the enhancement factor on wet deposition was tested and found to be relatively robust. An increase in the enhancement factor from 2 to 6 resulted in increases in UK wet deposition of oxidised $\mathrm{N}$ and $\mathrm{S}$ of 9 and $6 \%$, respectively.

Key words: Atmospheric composition and structure (pollution - urban and regional) - Meteorology and atmospheric dynamics (precipitation)

\section{Introduction}

Wet deposition in simple long-range transport models of acid deposition is treated as a loss term, based upon observed scavenging rates. However, for the UK conditions, a particular aspect of wet deposition requires careful consideration: the orographic enhancement of deposition from the seeder-feeder effect. Orographic enhancement of precipitation by the seeder-feeder effect is a widely observed and well understood phenomenon whereby precipitation is enhanced over high ground as a result of precipitation from high-level clouds (the seeder cloud) scavenging locally generated cap-cloud (the feeder cloud) on hill and mountain tops.

The process of orographic enhancement of precipitation was first described by the hydro-meteorologist Tor Bergeron in 1950 (Bergeron, 1950) who referred to 'releaser' and 'spender' clouds. The terms 'seeder' and 'feeder' clouds were first used in 1960 (Bergeron, 1960). Bergeron outlined a mechanism whereby clouds at an upper air level (typically cirrostratus, altostratus or 
cumulonimbus) 'seed' clouds at a lower level enveloping, or formed immediately above, hills (typically nimbostratus, stratus or the base of cumulonimbus; sometimes referred to as orographic stratus) which 'feed' upon the precipitation from above. Bergeron's detection of the effect originated from testing rain gauges (Pluvius gauges) in an area of approximately $1000 \mathrm{~km}^{2}$ around Uppsala which was relatively flat, such that no orographic effects were expected (Andersson, 1980/1981). However, subsequent analyses revealed a clear orographic effect induced by hills of $60 \mathrm{~m}$. Bergeron (1961) coined, and preferred, the word 'oreigenic' (i.e. borne by the mountain), rather than orographic (i.e. describing the mountain).

Since Bergeron's $(1950,1960,1961)$ foundational work, much effort has been devoted to examining the process of orographic enhancement of precipitation. However, not all orographic precipitation is the result of the seeder-feeder effect. Smith (1979) categorises the orographic control of precipitation in three ways: broadscale up-slope rain, small-scale redistribution of rain by hills (i.e. the seeder-feeder effect) and orographicconvective showers. In addition, lee-waves can result in orographic enhancement of precipitation. These processes are represented in Fig. 1.

However, the seeder-feeder mechanism has further effects in the transfer of pollutants to the ground. It has been shown that the concentrations of ions such as sulfate, nitrate and ammonium in cloud-water are much higher than those observed in precipitation (Dollard et al., 1983) such that scavenged cap-cloud results in enhanced wet deposition at altitude (Fowler et al., 1988). This process is illustrated in Fig. 2.

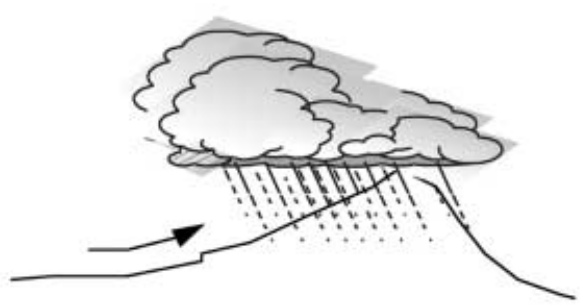

Broad scale upslope orographic precipitation

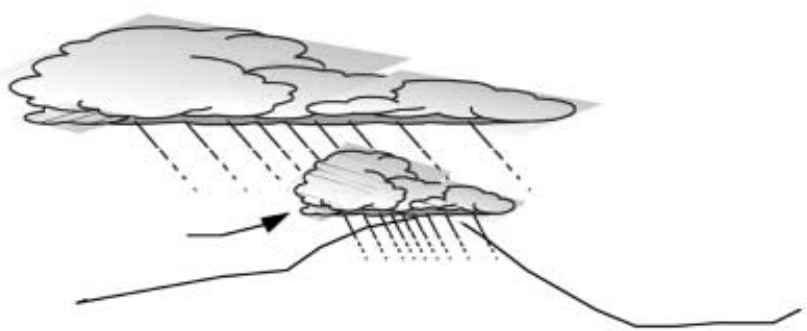

seeder-feeder orographic precipitation
The precipitation composition monitoring network for the UK currently comprises 32 sites, none of which are located at very high elevations for ease of sample collection (RGAR, 1997; Campbell and Lee, 1996). Thus, in order to map deposition, precipitation composition is interpolated between these sites and multiplied by a $20 \mathrm{~km}$ field of precipitation amount based upon measurements at over 4000 locations within the UK. Whilst this method for calculating deposition accounts for orographic enhancement of precipitation over high ground, it does not account for variation of its composition with altitude as a result of scavenging of capcloud. Thus, a simple methodology has been devised to account for this process based upon observations of deposition enhancement (Dore et al., 1992a). This increases estimates of deposition of inorganic ions at high elevations.

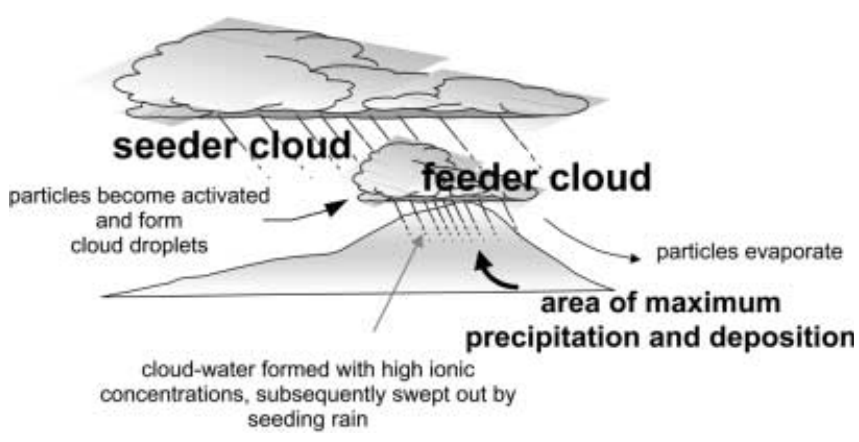

Fig. 2. The seeder-feeder process of the orographic enhancement of wet deposition

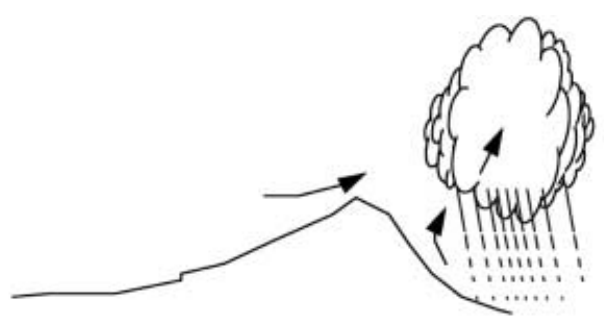

orographic convective showers

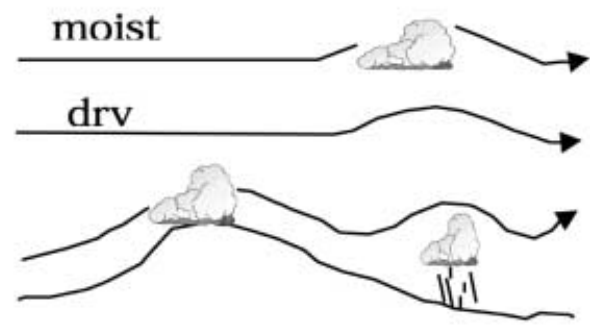

lee-waves

Fig. 1. Four mechanisms of orographic enhancement of precipitation 
A full description of the orographic enhancement of wet deposition would be difficult to incorporate within a long-range transport model. It would, of course, be possible to use the same procedure as that adopted for mapping measurements of wet deposition to 'enhance' the model output. However, this would destroy massconservation and distort source-receptor relationships, rendering the approach of limited use. The current generation of long-range transport models are still rather simple in their description of physical processes, such that it would be impossible to represent the origin of pollutants within seeder and feeder clouds and their subsequent scavenging without a vast increase in their complexity.

A simple parametrisation of the orographic enhancement of wet deposition had previously been incorporated into the long-range transport model described here, whereby washout factors were increased by a fixed factor, over a threshold precipitation amount, that does not subsequently vary with additional precipitation. This essentially represents a free parameter fit and the best fit was found for a threshold precipitation amount of $1200 \mathrm{~mm}$ with a fixed enhancement of washout coefficients by a factor of 3, above this threshold (Lee et al., 2000a). Such a representation, however, has its problems in that it is not well physically based. Furthermore, it assumes that the effect occurs with equal frequency in all wind directions, which is certainly not the case.

The revised parametrisation of the wet deposition process and its application in a long-range transport model is our subject here. The implementation of a revised wet deposition scheme is described in Sect. 2. The model is run for a number of test cases and these are given in Sect. 3. Finally, the implications are discussed in Sect. 4.

\section{Long-range transport model}

\subsection{Model framework}

The long-range transport model is a long-term annual average receptor-oriented Lagrangian box model assuming instantaneous dispersion on the vertical plane, when used in single-layer mode, or using $K$-diffusion theory (e.g. Seinfeld, 1986) to describe vertical diffusion for the multi-layer version. It has been described in detail (including parameters used), elsewhere (Lee et al., 1999, 2000a, b). It may be used at spatial resolutions typically varying from $150 \mathrm{~km}$ to $20 \mathrm{~km}$.

The air parcel picks up emissions from a regular grid system and integrates differential equations of chemical production and loss by wet and dry deposition of 22 species. Both primary and secondary pollutants are subject to wet and dry deposition. The concentration of a species at a particular point on a trajectory is a function of its airborne concentration at an earlier time (i.e. the value recorded on the same trajectory one step further away from the receptor) and the local emission and deposition fluxes: $\frac{\mathrm{d} c_{i}}{\mathrm{~d} t}=E_{i}+R_{i}\left(c_{j}\right)-v_{g_{i}} c_{i} / h-\Lambda_{i} c_{i}$

where $c_{i}$ concentration of species $i\left(\mathrm{~g} \mathrm{~m}^{-3}\right) ; t$ time (s); $E_{i}$ emission rate of species $i\left(\mathrm{~g} \mathrm{~s}^{-1}\right) ; R_{i}\left(c_{j}\right)$ rate of change of species $i$ as a result of the chemical reactions of itself and other species $j$; $v_{g i}$ dry deposition velocity of species $i$ $\left(\mathrm{m} \mathrm{s}^{-1}\right) ; h$ vertical depth over which dry deposition takes place $(\mathrm{m}) ; \Lambda_{i}$ washout (wet deposition) coefficient of species $i\left(\mathrm{~s}^{-1}\right)$.

Concentrations of all chemical species are set to zero at the beginning of each $96 \mathrm{~h}$ trajectory with the exception of ozone $\left(\mathrm{O}_{3}\right)$ and radical species $\left(\mathrm{OH}, \mathrm{NO}_{3}\right)$ and are evolved from emissions, chemical transformations and wet and dry removal processes.

Wet deposition in long-range transport models is usually represented by a simple loss coefficient (or washout coefficient) of the relevant species, based upon observations of the ratio of the species in air and rain, usually specific to a given precipitation amount. Previously, wet deposition, $W$, on a trajectory incoming at bearing $\theta$, was described by a 'constant drizzle' coefficient and a precipitation rate, i.e.:

$W_{g, s, \theta}=\Lambda_{s} c_{s, g} \frac{R_{g}}{\bar{R}}$

where $\Lambda$ is the scavenging coefficient for species $s, c$ is the concentration of species $s$, at grid cell $g, R_{g}$ is the precipitation rate at grid cell $g$, and $\bar{R}$ is the average precipitation rate for the UK. The washout coefficients used were based upon those given by Derwent (1987). This equation may be used to calculate $\Lambda$ at all points along the trajectory, with the total wet deposition at the receptor being the sum of all incoming trajectories, weighted by the windrose:

$W_{g, s}=\sum_{\theta} p_{\theta} W_{g, s, \theta}$

where $p$ is the wind frequency for each of 24 angular sectors.

In other trajectory models (e.g. Derwent et al., 1988; Metcalfe et al., 1995) the constant drizzle approach has been taken to describe wet deposition but weighting at a receptor has been by a wind rose, as in Eq. (3). However, a wind rose does not necessarily describe the arrival of precipitation by direction accurately. Here, a method is described which introduces weighting factors to reflect the dependence of deposition rate upon the variation in precipitation from place to place and upon wind direction.

The orographic component of precipitation makes a significant contribution to total precipitation at many upland sites in the UK. However, not all orographic precipitation is the result of the seeder-feeder process. The seeder-feeder process is primarily associated with frontal conditions, particularly, the warm sector. Thus, it would be incorrect to assume, for example, that easterly winds make an equal contribution to increases of wet deposition at upland sites as a result of the seederfeeder process. Furthermore, it is clear that if a 
significant fraction of orographic precipitation is the result of the seeder-feeder process over the course of a year, then this precipitation also arrives from frontal conditions. It is therefore concluded that in order to improve parametrisation of wet deposition, including the contribution of the seeder-feeder process, it is not only desirable but also necessary to have a directional description of precipitation scavenging. An improved model, incorporating directional precipitation scavenging, would include:

1. An estimate of orographic and non-orographic components of precipitation accounting for spatial variation

2. An estimate of precipitation amount and type by wind direction

3. A parametrisation of washout of the orographic component of precipitation which arises from the seeder-feeder process

A generalised solution incorporating these features would be:

$W_{g, s, \theta}=\Lambda_{s} c_{s, g} \frac{R_{g}}{\bar{R}}\left(F_{\theta} \frac{f_{g, \theta}^{o}}{f_{g}^{o}}\left(1-S_{g}\right)+\frac{f_{g, \theta}^{n}}{f_{g}^{n}} S_{g}\right)$

where $R$ is the annual precipitation rate at any site, $g, \bar{R}$ is the mean annual precipitation rate over the UK land mass, $S$ is the fraction of precipitation that is nonorographic, and $f$ is a precipitation factor in orographic and non-orographic cases denoted by superscripts $o$ and $n$, respectively, for direction $\theta$. A multiplying factor $F$ is applied to the scavenging coefficient, $\Lambda$, on the orographic component of precipitation only in order to represent the higher concentrations of pollutants found in cloud-water and scavenged during seeder-feeder events. The derivation of these terms is given in the following sections.

\subsection{Orographic and non-orographic precipitation}

In order to calculate the potential enhancement of wet deposition from the seeder-feeder process using measurements of precipitation composition, Dore et al. (1992a) identified the location of orographic enhancement of precipitation by linear interpolation of coastal precipitation amounts across the UK in a west to east gradient. This is then considered to be the amount of precipitation which would have occurred in the absence of any change in terrain over the distance, so that the additional precipitation observed is the result of orographic enhancement by the seeder-feeder process. Implicit in this assumption is that all orographic precipitation in the UK is the result of the seeder-feeder process and that it occurs solely in westerly trajectories as a result of frontal depressions.

In the absence of data on orographic and nonorographic components of precipitation across the UK, a similar approach to that of Dore et al. (1992a) allows identification of these components for acid deposition modelling purposes. The non-orographic component of
UK precipitation was determined (using the $5 \mathrm{~km}$ long term average 1941-1970) annual data by a simple interpolation between precipitation rates at coastal sites north, south, east and west of each inland square on a $20 \mathrm{~km}$ grid. The orographic component is therefore the difference between the total annual precipitation and the non-orographic precipitation. The advantage of this simple approach is that it preserves the original data on total precipitation across the UK according to the longterm UK Meteorological Office's map, and also identifies the location and ratio of orographic to nonorographic precipitation.

\subsection{The directionality of precipitation}

The directionality of both orographic and non-orographic precipitation is required to satisfy Eq. (4). For directional weighting of the non-orographic component, this is derived from 'rain-roses' provided by the ISMCS (1995) database that gives precipitation amount by wind direction at 47 locations across the UK. These are interpolated to give complete coverage of the UK.

For orographic precipitation, the directionality of precipitation amount necessary for Eq. (4) could be derived from data from the ISMCS (1995) database. However, this approach would have significant shortcomings as meteorological measurement stations are not usually located at high elevations and do not represent these areas well in the UK, where orographic enhancement of precipitation is most likely to occur. One alternative would be to interpolate precipitation amount (by direction) between these stations but considerable distortion of the spatial variability of precipitation is likely to arise because of the fine scale over which orographic enhancement of precipitation operates.

An alternative approach to deriving the orographic component of precipitation by direction that accounts for the magnitude and spatial variability of the orographic effect is to use a model, such as that described by Weston and Roy (1994). This model is formulated as follows:

$$
\begin{aligned}
& \Delta c l=q_{z} \Delta z+\bar{w} q_{z} \frac{\Delta x}{v}-\frac{\Delta x}{v} R \\
& R=k\left(c l-c l_{0}\right), \quad \text { for } c l \geq c l_{0} ; R=0, \text { otherwise }
\end{aligned}
$$

where $c l$ is the liquid water content of a cloud column, $\Delta c l$ is the change in $c l$ over horizontal distance $\Delta x$, and $c l_{0}$ is a threshold below which no rain occurs, $q_{z}$ is the rate of increase of $c l$ as the cloud column lifts over the terrain, $\Delta z$ is the change in altitude over distance $\Delta x, \bar{w}$ is the largescale vertical velocity, $v$ is the horizontal speed, $k$ is a constant $\left(1 / t_{\text {(cloudwater } \rightarrow \text { rainwater })}\right), R$ is the rainfall rate.

This model operates by evolving $\mathrm{cl}$, and hence $R$, along a straight-line trajectory $x$. For no change in altitude, the initial precipitation rate is maintained by the balancing of the two right-most terms in Eq. (5). Altitude takes effect through the first term on the 
right-hand side, any increase leading to an increase in precipitation rate and a subsequent depletion of cloudwater content, so that exposed hills experience precipitation whilst areas in the lee of such hills experience decreased precipitation, or a 'rain shadow'. This simple model takes into account the effect on precipitation of the lifting of a cloud column by hills resulting in orographic enhancement, but does not discriminate whether this is the result of large-scale effects, convective processes, coastal enhancement or seeder-feeder enhancement.

The Weston and Roy (1994) model was used in a study of the directionality of precipitation amount in Scotland and shown to operate well, albeit under rather limited conditions of northerly flow. For the present application it is clear that there are two possible approaches. Firstly, one might initialise the cloud column such that it gives actual mean directional precipitation over the sea, giving a direct prediction of the directional and total precipitation at each receptor site. This approach has the difficulty that the total precipitation amount at each site must match that of the Meteorological Office long-term precipitation distribution; an unlikely prospect, given the simplicity of the Weston and Roy (1994) model. Secondly, one might initialise the cloud column with a 'typical' precipitation rate, independent of direction or position, so that the calculated directional precipitation rates at each receptor constitute relative weighting factors for precipitation by direction. In the present application, total annual precipitation is available as a separate input, and the Weston and Roy (1994) model is best used for the calculation of the directional weighting factor $f_{\theta}$, see Eq. (4). Consequently, incoming straightline trajectories were initialised with a uniform precipitation rate of $1 \mathrm{~mm} \mathrm{~h}^{-1}$, independent of direction, with other model parameters taking the values specified as default in the original application of Weston and Roy (1994).

Validation of this model is rather difficult, as data on a sufficiently detailed spatial scale are not readily available. However, Weston and Roy (1994) validated their model in northerly flow and it showed good agreement with both amount and distribution of precipitation.

\subsection{The parametrisation of additional scavenging arising from the seeder-feeder effect}

The final stage in parameterising orographic effects on wet deposition is to determine an additional factor $F$, to be applied to the orographic component of precipitation. In essence, $F$ represents the concentration factor of pollutants in cloud-water in feeder rain at the high elevation site, over that of seeder rain experienced at the low-level upwind location.

The factor $F$, has been derived from data from event sampling during field campaigns made to determine the magnitude of seeder-feeder enhancement of deposition. The following ratios are defined:
$F_{t}=$ concentration in precipitation on hilltop/concentration in precipitation upwind of hill,

$F_{r}=$ precipitation recorded on hilltop/precipitation at upwind station,

$F=$ concentration in precipitation from cap-cloudwater/concentration in seeder precipitation.

According to Fowler et al. (1988), a simplified description of the seeder-feeder enhancement of orographic deposition can be described as:

$R$ at altitude $=R_{f}+R_{s}$

where it is assumed that the precipitation $R$ at the hilltop is the sum of seeder precipitation, $R_{s}$, and scavenged cap-cloud, $R_{f}$, or the feeder precipitation. The same amount of seeder precipitation, $R_{s}$, is assumed to fall on the hilltop and at the upwind station and this precipitation component is assumed to have the same concentration at both locations. The total amount of precipitation at the hilltop is given by:

$R_{f}+R_{s}=F_{r} R_{s}$

and the deposition on the hilltop is:

$c_{s} R_{s}+c_{f} R_{f}=c_{s} R_{s}+\left(F c_{s}\right) R_{f}$

The ratio of these quantities is the concentration at the hilltop:

$\frac{c_{s}\left(R_{s}+F R_{f}\right)}{F_{r} R_{S}}$

Dividing this expression by $c_{s}$ gives the ratio $F_{t}$ :

$F_{t}=\frac{R_{s}+F R_{f}}{F_{r} R_{s}}$

and, since from Eq. (9) we have

$R_{f}=R_{s}\left(F_{r}-1\right)$

we obtain by substitution and elimination

$F_{t}=\frac{1+F\left(F_{r}-1\right)}{F_{r}}$

i.e.

$F=\frac{F_{t} F_{r}-1}{F_{r}-1}$

This expression allows $F$ to be calculated from a review of the observations given in Table 1. However, not all these data can be used, only those that are for identified seederfeeder events. Table 2 gives estimates of the factor $F$ based on the events listed in Table 1. On these selected occasions, cap-clouds were present and orographic enhancement was presumably happening as a result of the scavenging of cap-cloud-water by seeder rain falling through the cap-cloud. The results of these calculations are rather variable but indicate values of about 3 for $F$.

A shortcoming in this approach is the assumption that precipitation from the seeder cloud is the same at the base and summit of the hill. It is not possible to determine this empirically and in practice, ascent of 


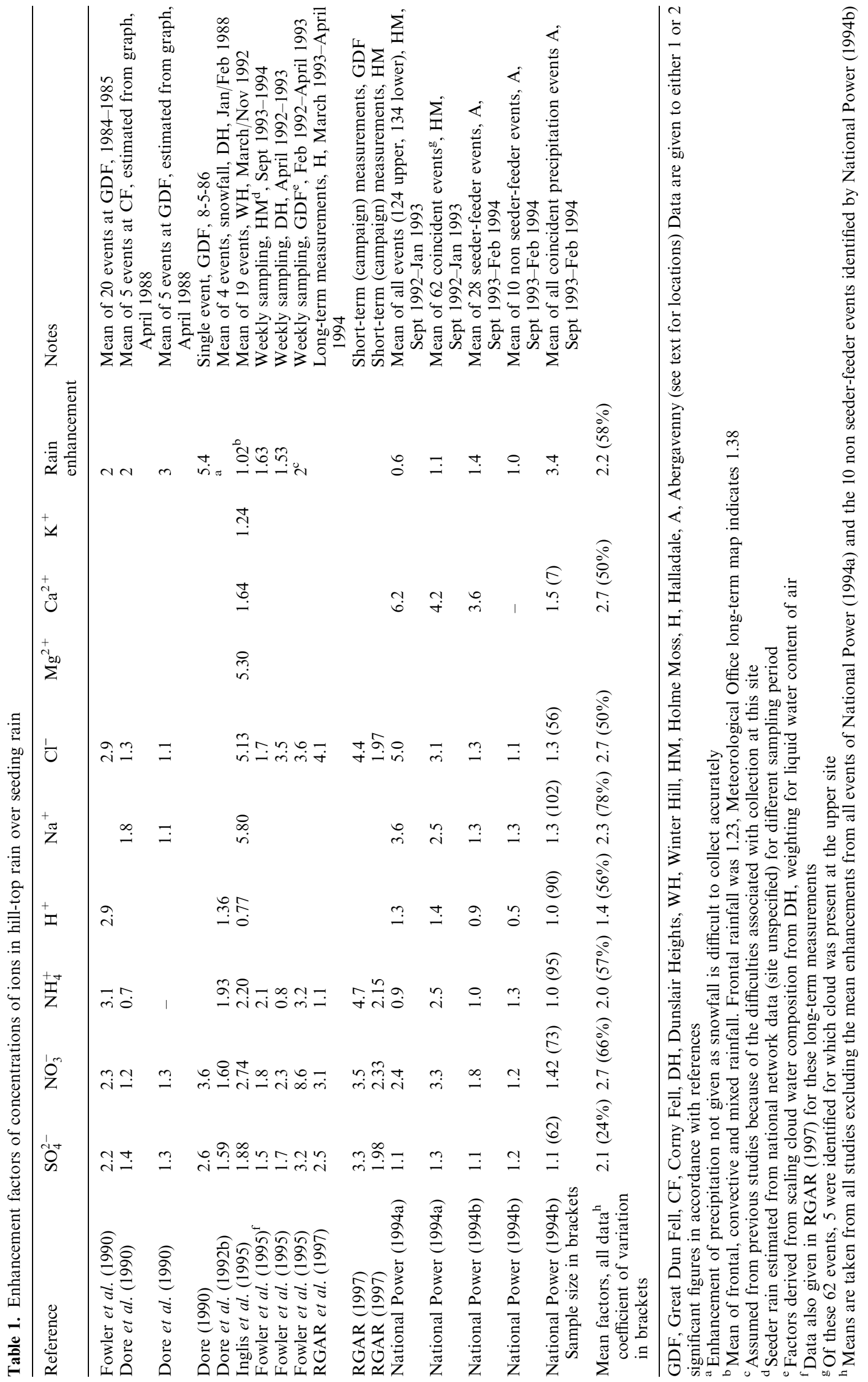


Table 2. Derivation of enhancement of cloud water concentrations from observational data

\begin{tabular}{|c|c|c|c|c|c|c|c|c|c|c|c|c|}
\hline Reference & $F_{r}$ & $\begin{array}{l}F_{t} \\
\mathrm{SO}_{4}^{2-}\end{array}$ & $\begin{array}{l}F_{t} \\
\mathrm{NO}_{3}^{-}\end{array}$ & $\begin{array}{l}F_{t} \\
\mathrm{NH}_{4}^{+}\end{array}$ & $\begin{array}{l}F_{t} \\
\mathrm{Na}^{+}\end{array}$ & $\begin{array}{l}F_{t} \\
\mathrm{Cl}^{-}\end{array}$ & $\begin{array}{l}F \\
\mathrm{SO}_{4}^{2-}\end{array}$ & $\begin{array}{l}F \\
\mathrm{NO}_{3}^{-}\end{array}$ & $\begin{array}{l}F \\
\mathrm{NH}_{4}^{+}\end{array}$ & $\begin{array}{l}F \\
\mathrm{Na}^{+}\end{array}$ & $\begin{array}{l}F \\
\mathrm{Cl}^{-}\end{array}$ & $\begin{array}{l}\text { Number of } \\
\text { events }\end{array}$ \\
\hline Fowler et al. (1988) & 2 & 2.2 & 2.3 & 3.1 & & 2.9 & 3.4 & 3.6 & 5.2 & & 0.8 & 20 \\
\hline Dore et al. (1990) & 3 & 1.3 & 1.3 & - & 1.1 & 1.1 & 1.5 & 1.5 & & 1.2 & 1.2 & 5 \\
\hline Dore (1990) & 5.4 & 2.6 & 3.6 & & & & 3.0 & 4.2 & & & & $\begin{array}{r}1 \\
31\end{array}$ \\
\hline Number of events $(n)$ & & & & & & & 31 & 31 & 25 & 10 & 30 & 127 \\
\hline Weighted mean $\times n$ & & & & & & & 87.2 & 90.4 & 106 & 18.8 & 109.8 & 412.2 \\
\hline Overall average $F$ & & & & & & & & & & & & 3.25 \\
\hline
\end{tabular}

where: $F_{r}=$ precipitation recorded on hilltop/precipitation at upwind station

$F_{t}=$ concentration in precipitation on hilltop/concentration in precipitation upwind of hill

$F=$ concentration in precipitation from cap-cloud water/concentration in seeder precipitation

higher-level air over the general terrain will obviously have an effect on seeder precipitation rates. However, the extent of this effect is less likely to take place on the horizontal scale of the size of hills and mountains in the UK and the overall increase is accounted for in the determination of orographic and non-orographic precipitation.

Having derived all the terms given in Eq. (4), including directionality of orographic and non-orographic precipitation, it is necessary to place a directional constraint on $F$. There is evidence that enhancement of concentration due to cap-cloud contributing to precipitation in upland areas is frequent in some wind directions and rare in others (Fowler et al., 1988; National Power, 1994a, b). This is expected to represent the major source of variation in enhancement of concentration, and the use of an event-based enhancement factor in a limited range of trajectory directions in the model is believed to give a realistic estimate of deposition in areas where orographic enhancement is significant. The 'seeder-feeder roses' are shown in Fig. 3 (Rodgers and Webb, personal communication) and are taken from data reported by National Power (1994a, b). Radiosonde ascent data were taken from Cambourne, Aughton, Lark Hill, and Herstmonceaux to examine the likelihood of seederfeeder enhancement occurring. The roses show the frequency with which seeder-feeder events occurred at Abergavenny and Holme Moss. The figures clearly show, as might be expected, a southwesterly bias and that the frequency with which seeder-feeder events occur from easterly trajectories is very infrequent. This is consistent with seeder-feeder events occurring during frontal depressions moving in over the UK such that air is stratified and moist in the lower layers which is conducive to the activation of aerosols as they rise and cool over high ground, forming orographic cloud. Such conditions have been shown to be the main cause of orographic enhancement of precipitation by the seederfeeder effects. These data indicate the highest frequency of seeder-feeder enhancement originating from the southwest quadrant. Thus, in the application of $F$ in the model, this has been constrained to only operate in

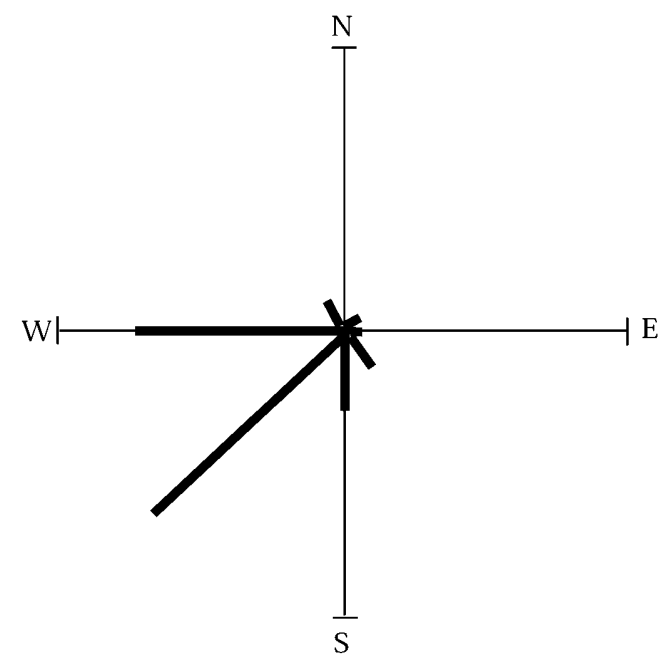

Fig. 3. 'Seeder-feeder rose' from Holme Moss and Abergavenny $($ total $=60$ events) $($ National Power, 1994a, b)

certain trajectories. The sensitivities of this directional constraint and the magnitude of $F$ are described in detail in Sect. 4.

\subsection{The effects of the presence of orographic cloud on the chemistry of the atmosphere}

In addition to the influence of the seeder-feeder process on wet deposition, the physical conditions of pollutants entering the cap-cloud which are subsequently scavenged, may also modify deposition rates from chemical interactions (Hill et al., 1986, 1987). It is now well established that as an air mass enters cloud, sulfur dioxide $\left(\mathrm{SO}_{2}\right)$ is involved in a reaction that results in the production of acidity. A particular example of this process is where the forced ascent of an air mass over a hill or ridge results in cooling and subsequent cap-cloud formation, as described. Laboratory studies (Penkett et al., 1979) demonstrated that the important oxidants for conversion of $\mathrm{SO}_{2}$ to sulfate are hydrogen peroxide $\left(\mathrm{H}_{2} \mathrm{O}_{2}\right)$ and ozone $\left(\mathrm{O}_{3}\right)$. Both reactions are $\mathrm{pH}$ dependent, the reaction with $\mathrm{H}_{2} \mathrm{O}_{2}$ being more important 
below $\mathrm{pH} 4$ and the reaction with $\mathrm{O}_{3}$ being more important above $\mathrm{pH} 5$.

Several field experiments have been conducted at Great Dun Fell (GDF) in Cumbria (Chandler et al., 1988a, b; Gallagher et al., 1990) with the objective of measuring the oxidation rate of $\mathrm{SO}_{2}$ in cloud. Great Dun Fell is part of the Pennine ridge in northern England that is frequently covered by a cap-cloud. Results from studies at GDF indicated that $\mathrm{SO}_{2}$ was oxidised and resulted in the production of acidic species. It was also concluded that the measured oxidation rate during the experiments was significantly faster than would have been predicted from the results derived in the earlier laboratory experiments. Most of the experiments at GDF demonstrated that $\mathrm{H}_{2} \mathrm{O}_{2}$ was the dominant oxidant. The cloud-water $\mathrm{pH}$ tended to be low or decreased as oxidation of $\mathrm{SO}_{2}$ occurred; the low $\mathrm{pH}$ allowing $\mathrm{H}_{2} \mathrm{O}_{2}$ to dominate oxidation. In a limited number of the studied events, the $\mathrm{pH}$ values remained relatively high thus allowing $\mathrm{O}_{3}$ to dominate oxidation. It was postulated that ammonia $\left(\mathrm{NH}_{3}\right)$ was present and responsible for neutralising the acid species produced in the cloud-water.

For the majority of cases in which $\mathrm{H}_{2} \mathrm{O}_{2}$ dominated oxidation, the reaction rate was expressed in terms of:

$\frac{\mathrm{dS}}{\mathrm{dt}}=k^{\prime}\left[\mathrm{H}_{2} \mathrm{O}_{2}\right]\left[\mathrm{SO}_{2}(\mathrm{aq})\right]$

such that $k^{\prime}$ was approximately $\mathrm{pH}$ independent between values of 1 and 5 (Gallagher et al., 1990).

The reaction rates derived had a mean of $5.8 \times 10^{6}$ $1 \mathrm{~mol}^{-1} \mathrm{~s}^{-1}$ for the 1986 study (Chandler et al., 1988a) and a range of $1.2-5.8 \times 10^{6} 1 \mathrm{~mol}^{-1} \mathrm{~s}^{-1}$ for the 1988 study (Gallagher et al., 1990). The reaction is, therefore, relatively fast and should $2 \mathrm{ppb}$ of both $\mathrm{SO}_{2}$ and $\mathrm{H}_{2} \mathrm{O}_{2}$ be present in the gas phase and enter cloud under the observed conditions then over $95 \%$ of the $\mathrm{SO}_{2}$ would be oxidised within $5 \mathrm{~s}$. It was observed that the reaction tended to be oxidant limited, the amount of $\mathrm{H}_{2} \mathrm{O}_{2}$ available being significantly below that required for complete removal of the $\mathrm{SO}_{2}$. Measurement of the $\mathrm{H}_{2} \mathrm{O}_{2}$ in the cloud-water indicated that over $75 \%$ of the $\mathrm{H}_{2} \mathrm{O}_{2}$ was removed in less than $5 \mathrm{~min}$. Entrainment of free troposphere air was observed during some of the experiments, which contributed to the input of additional $\mathrm{H}_{2} \mathrm{O}_{2}$ and oxidation of some of the remaining $\mathrm{SO}_{2}$. The $\mathrm{H}_{2} \mathrm{O}_{2}$ concentrations were variable and ranged from 0.1-0.3 ppb. During the studies at GDF in 1986 (Chandler et al., 1988a) the concentration of $\mathrm{H}_{2} \mathrm{O}_{2}$ was of the order of 0.1 to $0.2 \mathrm{ppb}$ for a significant fraction of the time so that about $10 \%$ of available $\mathrm{SO}_{2}$ was converted very rapidly to acidic sulfate but further reaction was very slow. The $\mathrm{pH}$ of the cloud-water was too low to allow the $\mathrm{O}_{3}+\mathrm{SO}_{2}$ reaction to proceed to any significant rate.

The effect of the presence of orographic cloud on $\mathrm{SO}_{2}$ oxidation rates was previously ignored in the model (Lee et al., 2000a). However, Metcalfe et al. (1995) have incorporated this by setting the oxidation rate of $\mathrm{SO}_{2}$ to increase in unit steps for each additional $250 \mathrm{~mm}$ precipitation.
Here, a simplified representation has been adopted. Given that the grid squares are $20 \mathrm{~km} \times 20 \mathrm{~km}$ and that the wind speed is assumed to be a constant $7.5 \mathrm{~m} \mathrm{~s}^{-1}$, the transit time for an air mass to traverse the grid square is therefore $0.74 \mathrm{~h}$. It is assumed that $10 \%$ of the $\mathrm{SO}_{2}$ is removed very rapidly and little or no further reaction occurs and an average oxidation rate of $13.5 \% \mathrm{~h}^{-1}$ is used in the grid squares where orographic cloud is assumed to be present. The residence time of $0.74 \mathrm{~h}$ combined with the value of $13.5 \%$ results in a conversion of $10 \%$ of the initial $\mathrm{SO}_{2}$. The method described for identifying the amount and location of orographic precipitation provides a convenient basis for identifying where this change in the oxidation process of $\mathrm{SO}_{2}$ might occur, as the seeder-feeder process occurs where orographic cap-cloud forms. However, a continuous step change in the oxidation rate of $\mathrm{SO}_{2}$ to $13.5 \% \mathrm{~h}^{-1}$ would be incorrect, as this would assume that presence of cap-cloud for $100 \%$ of the time (on the annual time scale of the model). The amount of time that cap-cloud is present at GDF, for example, is approximately 200 days per year (for some fraction of the day). However in other parts of the country where orographic cloud forms on hills and mountain-tops, the occurrence may be far less frequent. In the absence of suitable data, the work of Weston (1992) was used as a basis for a UK-wide parametrisation. An approximation of cloud immersion frequencies from Weston's (1992) model for the UK is $10 \%$ of the time. This is a subjective estimation, in the absence of incorporating Weston's (1992) data into the model, but as a first approximation is probably sufficient. The enhanced oxidation rate of $\mathrm{SO}_{2}$ of $13.5 \% \mathrm{~h}^{-1}$ was therefore scaled accordingly to $1.3 \% \mathrm{~h}^{-1}$ over the whole $20 \mathrm{~km}$ grid cell within which, it was assumed that cap-cloud occurred, from the analysis of directional precipitation amounts and the trajectories in which $F$ was allowed to depart from unity.

\section{Results}

\subsection{Approaches to model validation}

A number of model runs were undertaken in order to quantify the consequences of the changes introduced into the model and to test the effect of new parameters.

A necessary part of this process is to compare the output of the model to measurements. However, this is not entirely straightforward as measurements of deposition from national network sites at a given location may not represent the average deposition rate to a given $20 \mathrm{~km} \times 20 \mathrm{~km}$ receptor in upland areas because of the orographic effect on precipitation and deposition and are modified to account for this effect (Dore et al., 1992a). Therefore, a combination of approaches was taken: firstly, total country budgets were compared with model output; secondly, the spatial patterns of deposition were compared with those of enhanced maps of deposition; and lastly, in sensitivity analyses, modelled deposition was compared with the enhanced measure- 
ment data for grid squares in which acid deposition sites lie.

United Kingdom budgets of species by wet, dry and cloud-water deposition are given in Table 3 (RGAR, 1997) for the period 1992-1994. The precipitation field used in determining these budgets was the average for that period. The same precipitation field was used in the modelling. The emissions used in the model were those for 1992, not the mean of the period 1992-1994. Emissions of $\mathrm{SO}_{2}$ and $\mathrm{NO}_{\mathrm{x}}$ have changed significantly over the period: $\mathrm{SO}_{2}$ from 1742 ktonne $\mathrm{S} \mathrm{y}^{-1}$ in 1992 to

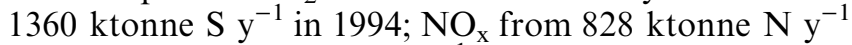

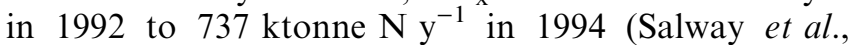
1996). The deposition budget figures in Table 3 have been corrected for land/water areas at coastline $20 \mathrm{~km}$ grid boxes, as is also the case for the country budgets from the model.

In order to understand the result of the changes in the model's formulation, it was run for four different development cases:

1. The basic model with no orographic enhancement parametrisation, with no directionality in precipitation, utilising wind roses to weight deposition at receptors ('run 1').

2. The previous version of orographic enhancement parametrisation (Lee et al., 2000a) with no directionality of precipitation, utilising wind roses to weight deposition at receptors and enhancement of the wet scavenging factors by 3 for aerosol species at receptors where the annual rainfall $\geq 1200 \mathrm{~mm} \mathrm{y}^{-1}$ ('run 2').

3. The new version of the model with directional precipitation fields, weighting wet deposition at receptors by the fraction of time that precipitation occurs from a particular direction but with no additional enhancement for seeder-feeder scavenging ('run 3').

4. The new version of the model with directional precipitation fields, weighting wet deposition at receptors by the fraction of time that precipitation occurs from a particular direction but enhancing the

Table 3. Deposition budgets for the United Kingdom for the period 1992-1994 (ktonnes S/ $\mathrm{N} \mathrm{y}^{-1}$ )

\begin{tabular}{lccc}
\hline Deposition process & Oxidised S & Oxidised N & Reduced N \\
\hline Wet deposition & 200 & 100 & 110 \\
Dry deposition & 140 & $40^{\mathrm{a}}$ & $110^{\mathrm{b}}$ \\
Cloud-water deposition $^{\mathrm{c}}$ & 10 & 10 & 10 \\
Totals & 350 & 150 & 230 \\
\hline
\end{tabular}

${ }^{a}$ This represents dry deposition of $\mathrm{NO}_{2}$ alone, not $\mathrm{NO}_{\mathrm{y}}$, of which other $\mathrm{N}$ species maybe significant components

${ }^{b}$ This is derived from an $\mathrm{NH}_{3}$ concentration field which is from model output (RGAR, 1997) and therefore has very large uncertainties which is exacerbated by dry deposition process model uncertainties in direction and magnitude of fluxes of $\mathrm{NH}_{3}$ over annual periods

${ }^{\mathrm{c}}$ Cloud-water deposition is determined from measurements at two sites combined with a modelled distribution of cloud frequency statistics (RGAR, 1997; CLAG, 1994) orographic component of precipitation by a factor of 3 in trajectories from approximately the south to the north (i.e. sectors 6-12, where sector 1 is due north). This formulation is the 'idealised' version from the preceding discussions of model formulation (Sect. 2) ('run 4').

The UK country deposition budget results of these model runs are given in Table 4 and wet deposition of non sea-salt $\mathrm{S}$ are shown in Fig. $4 \mathrm{a}-\mathrm{d}$, wet oxidised $\mathrm{N}$ in Fig. 5a-d, and the enhanced deposition measurements in Fig. 6a, b. The two species considered in detail are S and oxidised $\mathrm{N}$ deposition. Some results of reduced $\mathrm{N}$ deposition are reported for completeness but are not considered in any detail.

\subsection{Modelled wet deposition of non sea-salt $S$ to the $U K$}

The effects of the model changes are insignificant for dry deposition of $\mathrm{S}$ species, with the modelled deposition budget remaining relatively constant at 136137 ktonnes $\mathrm{S} \mathrm{y}^{-1}$, which agrees well with the dry budget derived from measurements resulting in 140 ktonnes $\mathrm{y}^{-1}$. $\left(\mathrm{SO}_{2}\right.$ concentrations have been measured, to which a process-based dry deposition model has been applied, see RGAR 1997.) However, the different model formulations have quite marked effects on the modelled wet deposition of non sea-salt $\mathrm{S}$. The basic model (run 1) predicts $82 \%$ of that derived from the UK country wet deposition budget (see Sect. 6 for discussion of derivation of UK country budgets), whilst the basic parametrisation of orographic enhancement (run 2) appears to perform 'best', predicting $92 \%$ of the UK country deposition budget of 350 ktonnes $\mathrm{y}^{-1}$. The new directional model (runs 3 and 4) predict 81 and $84 \%$ of the UK country deposition budget.

The figures of modelled wet deposition of non seasalt $\mathrm{S}$ show rather more detail than the UK deposition budgets. The basic model formulation (run 1, Fig. 4a) predicts higher rates of deposition in the wet upland areas of England and Wales (i.e. $>8 \mathrm{~kg} \mathrm{~S} \mathrm{ha}^{-1} \mathrm{y}^{-1}$ ) and are of the order of $<8 \mathrm{~kg} \mathrm{Sha}^{-1} \mathrm{y}^{-1}$ for much of Scotland, despite the high precipitation rates. The basic formulation of orographic enhancement (run 2, Fig. 4b) results in much higher rates of deposition to Scotland, but also to the Pennines and Wales resulting in rates $>16 \mathrm{~kg} \mathrm{~S} \mathrm{ha}^{-1} \mathrm{y}^{-1}$. The revised model formulation including directional precipitation fields (run 3, Fig. 4c) results in a similar pattern of deposition to the basic model (run 1, Fig. 4a). The spatial pattern of wet $\mathrm{S}$ deposition from run 4 (Fig. 4d) with enhanced scavenging accounting for the seeder-feeder effect in the western sectors shows a similar pattern to that of run 3 , but with higher deposition rates in Scotland, whilst those to the Pennines and Wales are little changed.

If these figures are compared with the spatial pattern of enhanced wet $\mathrm{S}$ deposition derived from measurements (Fig. 6a), it is clear that the basic model (run 1) appears to slightly underestimate deposition in 
Table 4. Modelled country deposition budgets of oxidised $\mathrm{S}$ and $\mathrm{N}$ and reduced $\mathrm{N}$ for different model conditions $\left(\mathrm{ktonnes} \mathrm{S} / \mathrm{N} \mathrm{y}^{-1}\right)$

\begin{tabular}{|c|c|c|c|c|c|}
\hline Species & $\begin{array}{l}\text { Run } 1 \\
\text { simple model, } \\
\text { no enhancement }\end{array}$ & $\begin{array}{l}\text { Run } 2 \\
\text { 'old' orographic } \\
\text { enhancement scheme }\end{array}$ & $\begin{array}{l}\text { Run } 3 \\
\text { version } 1.2 \text {, revised } \\
\text { directional scavenging } \\
F=1\end{array}$ & $\begin{array}{l}\text { Run } 4 \\
\text { version } 1.2 \text {, revised } \\
\text { directional scavenging, } \\
\text { enhanced in sectors } 6-11 \text {, } \\
F=3\end{array}$ & $\begin{array}{l}\text { RGAR } \\
\text { 92-94 deposition } \\
\text { budgets }\end{array}$ \\
\hline Dry $N^{\mathrm{a}}$ (oxidised) & 53 & 52 & 53 & 52 & 40 \\
\hline Wet N (oxidised) & 74 & 101 & 75 & 79 & 110 \\
\hline Wet S (oxidised) & 149 & 186 & 148 & 158 & 210 \\
\hline Total S (oxidised) & 286 & 322 & 285 & 294 & 350 \\
\hline Dry N (reduced) & 93 & 93 & 93 & 93 & 110 \\
\hline Wet N (reduced) & 85 & 104 & 85 & 89 & 120 \\
\hline Total N (reduced) & 178 & 197 & 178 & 182 & 230 \\
\hline
\end{tabular}

${ }^{a}$ Dry $\mathrm{N}$ specified in model runs includes dry deposition of all $\mathrm{NO}_{\mathrm{y}}$ species calculated in the model, i.e. $\mathrm{NO}_{2}, \mathrm{HNO}_{3}$, $\mathrm{PAN}, \mathrm{HONO}$, and aerosol nitrate. However, RGAR dry $\mathrm{N}$ budget is $\mathrm{NO}_{2}$ only

the Pennines and grossly so in Scotland. The spatial pattern of deposition which includes a basic formulation of orographic enhancement appears to perform rather better in Scotland, but grossly over-predicts deposition rates in the Pennines and Wales. The pattern of deposition from the revised directional formulation of orographic enhancement is similar to that derived from measurements, does not grossly overpredict deposition rates in the Pennines and Wales but still under-predicts deposition to Scotland. However, this formulation (run 4) is clearly superior to the basic model (run 1).

\subsection{Modelled wet deposition of oxidised $N$ to the $U K$}

Many features of the results for oxidised $\mathrm{N}$ from changes to the model formulation are similar to those for wet $\mathrm{S}$ deposition. The UK dry deposition budget (Table 4) of the model predictions are very similar at $52-53$ ktonnes $\mathrm{N} \mathrm{y}^{-1}$. A direct comparison with the UK country dry deposition budget is not straightforward as this is derived from measurements of $\mathrm{NO}_{2}$ only, not $\mathrm{NO}_{\mathrm{y}}$. However, from analyses of model output, $\mathrm{NO}_{2}$ dry deposition is invariant at approximately 34 ktonnes $\mathrm{N} \mathrm{y}^{-1}$, accounting for $85 \%$ of the estimated dry $\mathrm{N}$ deposition of this species. For wet deposition, the basic model (run 1) accounts for $67 \%$ of the estimated UK country budget of wet deposited oxidised $\mathrm{N}$, the basic formulation of orographic enhancement (run 2) again appears 'best' giving a 92\% match, whereas the revised model runs (3 and 4) result in matches of 68 and $72 \%$, respectively.

The spatial patterns of wet deposition resulting from these runs again reveal rather more detail. The basic model (run 1) predicts deposition rates of the order of 4-6 kg N ha ${ }^{-1} \mathrm{y}^{-1}$ for the Pennines and Wales, and much smaller rates in Scotland. The basic formulation of orographic enhancement (run 2) results in much greater deposition rates; above $8 \mathrm{~kg} \mathrm{~N} \mathrm{ha}^{-1} \mathrm{y}^{-1}$ for much of Wales and the Pennines and 4$8 \mathrm{~kg} \mathrm{~N} \mathrm{ha}^{-1} \mathrm{y}^{-1}$ for high rainfall areas of Scotland. The pattern of deposition resulting from the revised directional model without seeder-feeder enhancement (run 3) is very similar to the basic model formulation (run 1), whereas the inclusion of seeder-feeder enhancement picks up higher deposition rates to parts of southern Scotland. In terms of a comparison with the pattern of wet deposition from the enhanced measurements, the basic model (run 1) under-predicts in all the high rainfall areas of the UK; the basic orographic model matches some of the patterns of deposition and deposition rates in Scotland but grossly over-predicts in the Pennines and Wales. The revised model with seederfeeder enhancement (run 4) provides the best match, but still under-predicts in Scotland.

\subsection{Sensitivity to the constraints of seeder-feeder enhancement in particular directions}

Since the directional dependence of seeder-feeder enhancement of $F=3$ is based upon observational data at two upland sites in the UK, it was necessary to determine the model's sensitivity to applying this enhancement in particular sectors. An enhancement of $F=3$ was applied in the following ways: to all sectors in run 5; to sectors 7-10 in run 6; sectors 6-11 in run 7; sectors 6-12 in run 8 . The UK country deposition budgets are given in Table 5 .

The modelled UK dry deposition budgets of both $\mathrm{S}$ and oxidised $\mathrm{N}$ showed very little sensitivity to the different directional dependencies. For wet deposited S and oxidised $\mathrm{N}$, there was little difference in the modelled country deposition budgets between a fairly narrow constraint of the application of seeder-feeder enhancement to sectors 7-10 (run 6) and a much broader constraint of sectors 6-12 (run 8). However, removing the directional constraint completely such that seeder-feeder enhancement was applied to the orographic component of precipitation in all directions resulted in an increase of wet deposition of $10 \%$ for both $\mathrm{S}$ and oxidised $\mathrm{N}$ over the constraint of enhancement to sectors 6-12.

Further comparisons have been made between the model output and the modified measurements of wet 


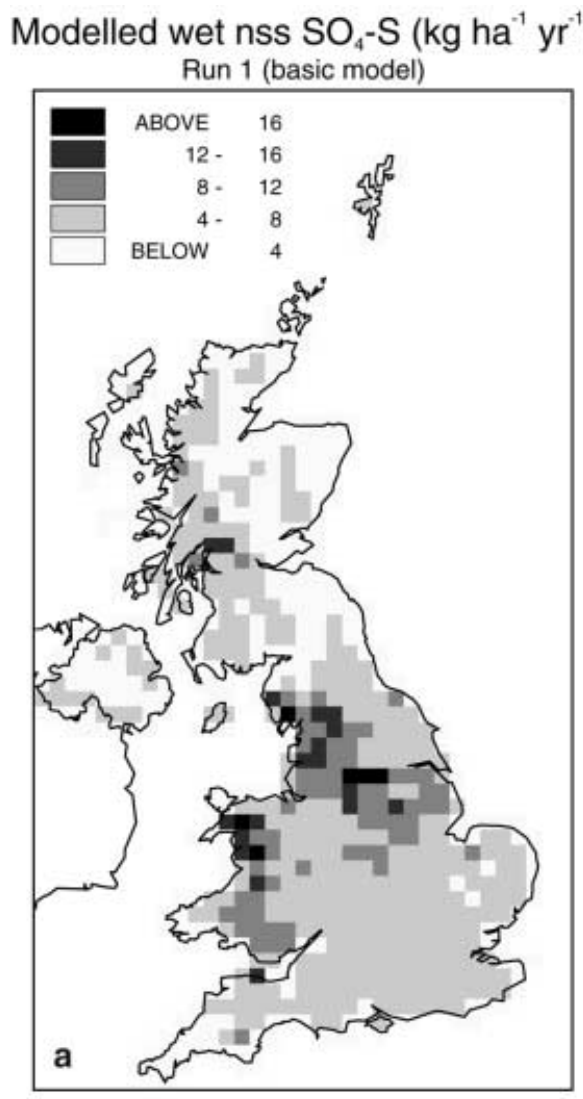

Modelled wet nss $\mathrm{SO}_{4}-\mathrm{S}\left(\mathrm{kg} \mathrm{ha}^{-1} \mathrm{yr}^{-1}\right)$ Run 3 (directional rain, no enhancement)

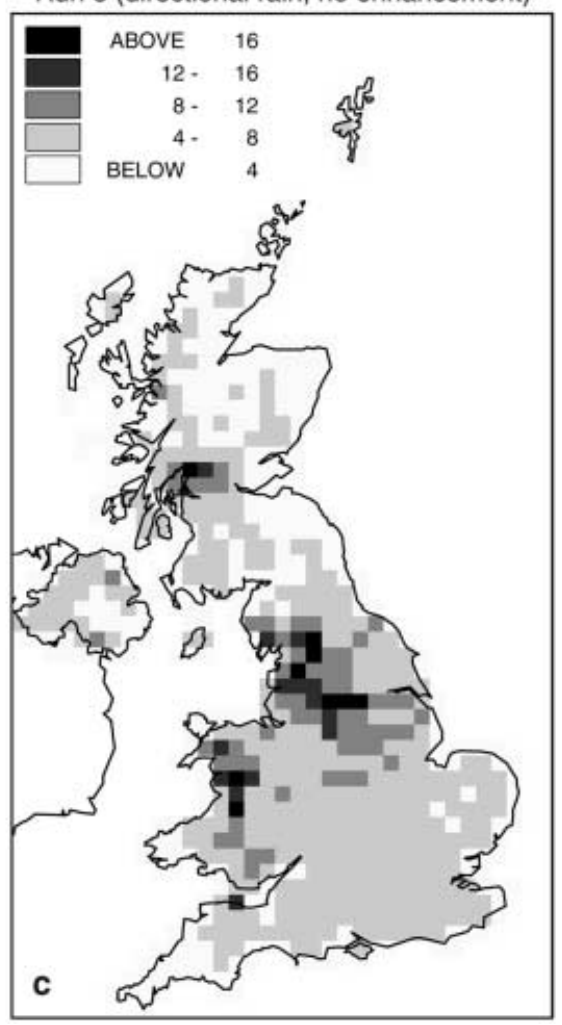

Modelled wet nss $\mathrm{SO}_{4}-\mathrm{S}\left(\mathrm{kg} \mathrm{ha}^{-1} \mathrm{yr}^{-1}\right)$

Run $2\left(\mathrm{~F}=3\right.$, when rain $\left.1200 \mathrm{~mm} \mathrm{yr}^{-1}\right)$

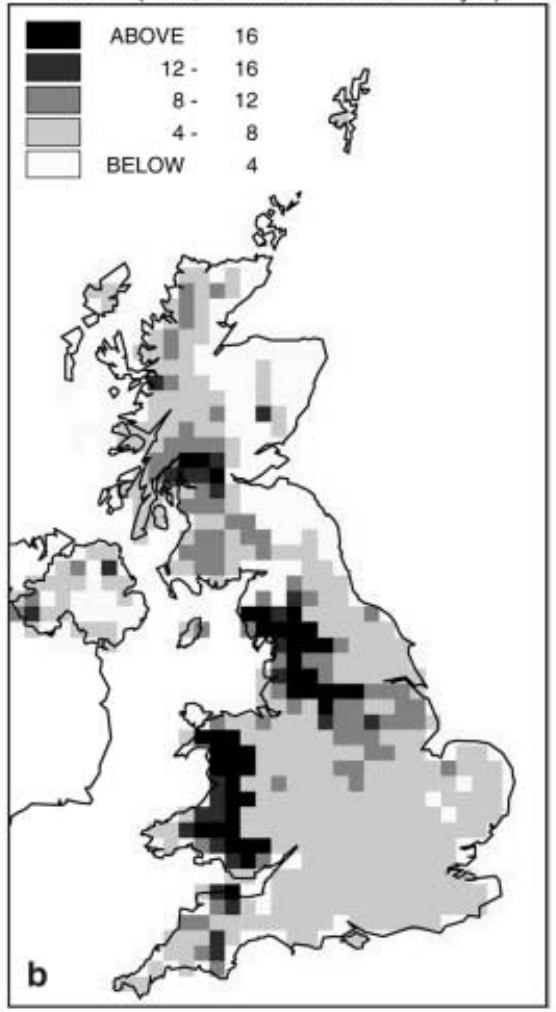

Modelled wet nss $\mathrm{SO}_{4}-\mathrm{S}\left(\mathrm{kg} \mathrm{ha}^{-1} \mathrm{yr}^{-1}\right)$

Run 4 (directional rain, enhancement $F=3$, sectors 6-11)

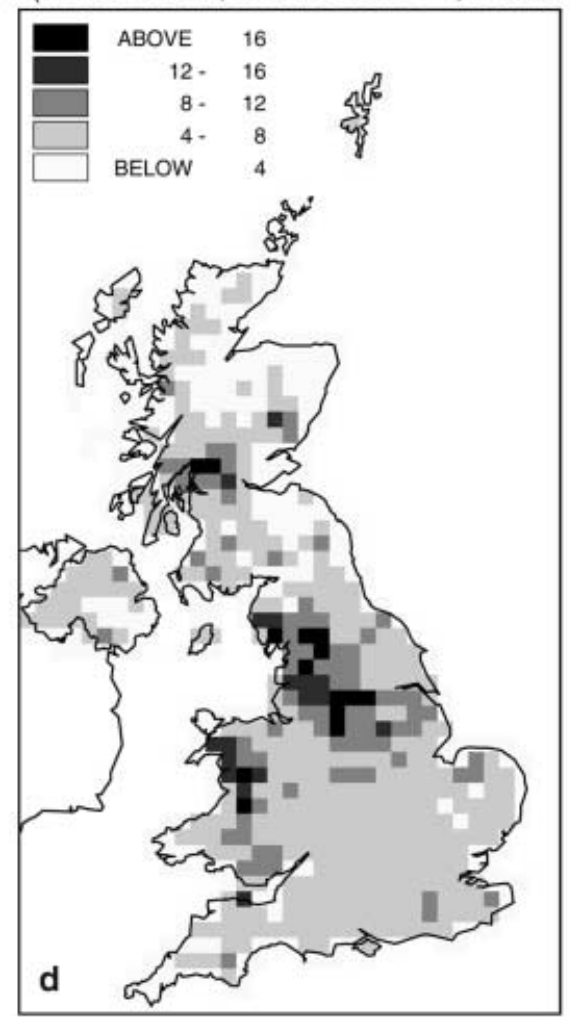

Fig. 4. a Modelled wet nss $\mathrm{SO}_{4}-\mathrm{S}$ $\left(\mathrm{kg} \mathrm{ha}^{-1} \mathrm{y}^{-1}\right)$, run 1 (basic model); b modelled wet nss $\mathrm{SO}_{4}-\mathrm{S}$ $\left(\mathrm{kg} \mathrm{ha}^{-1} \mathrm{y}^{-1}\right)$, run $2(F=3$, when rain $\left.>1200 \mathrm{~mm} \mathrm{y}^{-1}\right)$; $\mathbf{c}$ modelled wet nss $\mathrm{SO}_{4}-\mathrm{S}\left(\mathrm{kg} \mathrm{ha}^{-1} \mathrm{y}^{-1}\right)$, run 3

(directional rain, no enhancement); d modelled wet nss $\mathrm{SO}_{4}-\mathrm{S}$ $\left(\mathrm{kg} \mathrm{ha}^{-1} \mathrm{y}^{-1}\right)$, run 4 (directional rain, enhancement $F=3$, sectors 6-11) deposition in order to understand the implications of changing the directional dependence of enhancement in the model.
Data were taken for equivalent $20 \times 20 \mathrm{~km}$ receptors in which bulk deposition collectors are sited. These data are shown in Fig. $7 \mathrm{a}-\mathrm{d}$ for wet $\mathrm{S}$ deposition and Fig. 8a-d 
Modelled wet $\mathrm{NO}_{3}-\mathrm{N}\left(\mathrm{kg} \mathrm{ha}^{-1} \mathrm{yr}^{-1}\right)$

Run 1 (basic model)

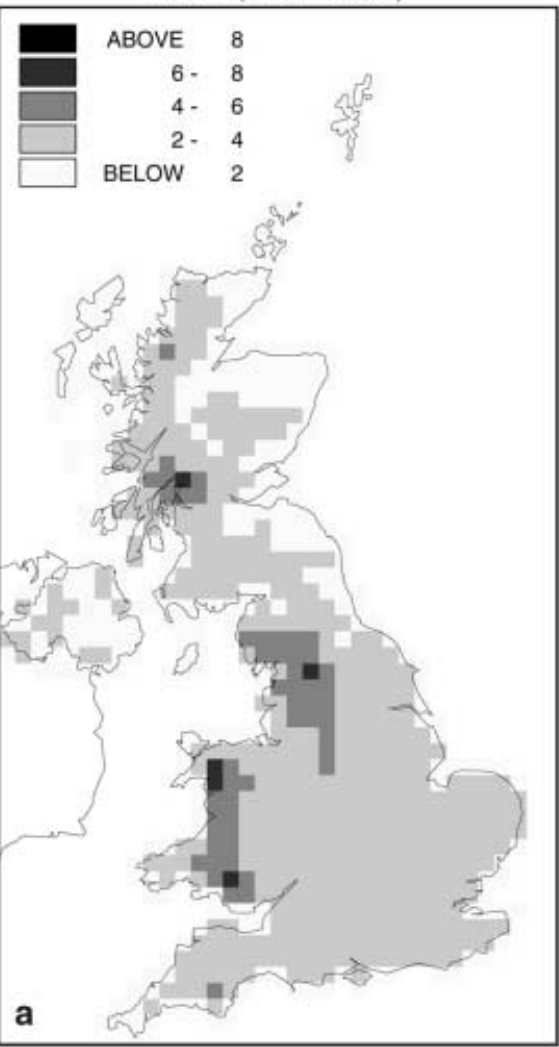

Modelled wet $\mathrm{NO}_{3}-\mathrm{N}\left(\mathrm{kg} \mathrm{ha}^{-1} \mathrm{yr}^{-1}\right)$

Run 3 (directional rain, no enhancement)

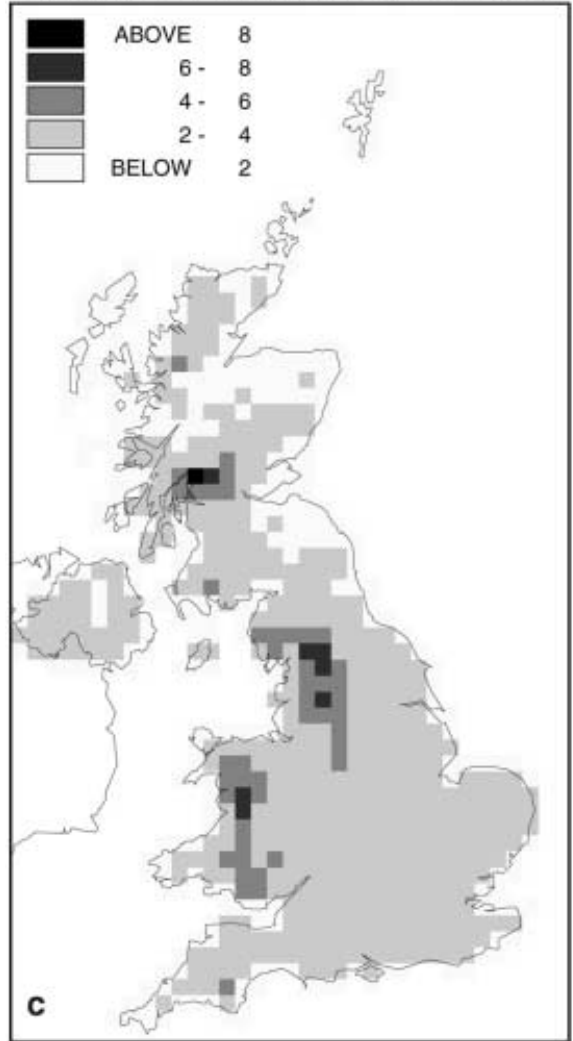

Modelled wet $\mathrm{NO}_{3}-\mathrm{N}\left(\mathrm{kg} \mathrm{ha}^{-1} \mathrm{yr}^{-1}\right)$

Run $2\left(\mathrm{~F}=3\right.$, when rain $\left.1200 \mathrm{~mm} \mathrm{yr}^{-1}\right)$

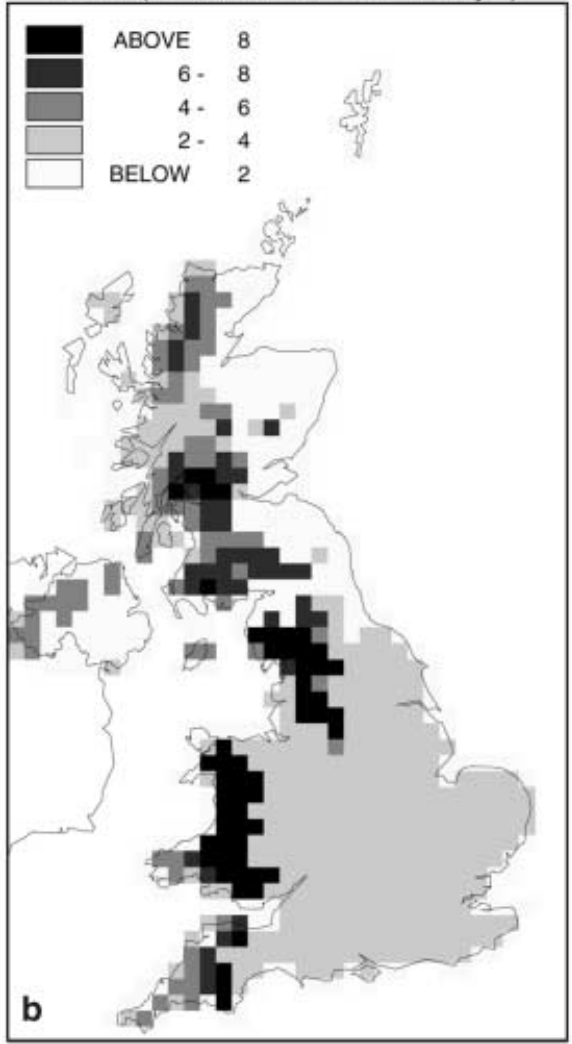

Modelled wet $\mathrm{NO}_{3}-\mathrm{N}\left(\mathrm{kg} \mathrm{ha}^{-1} \mathrm{yr}^{-1}\right)$

Run 4 (directional rain, enhancement $F=3$, sectors 6-11)

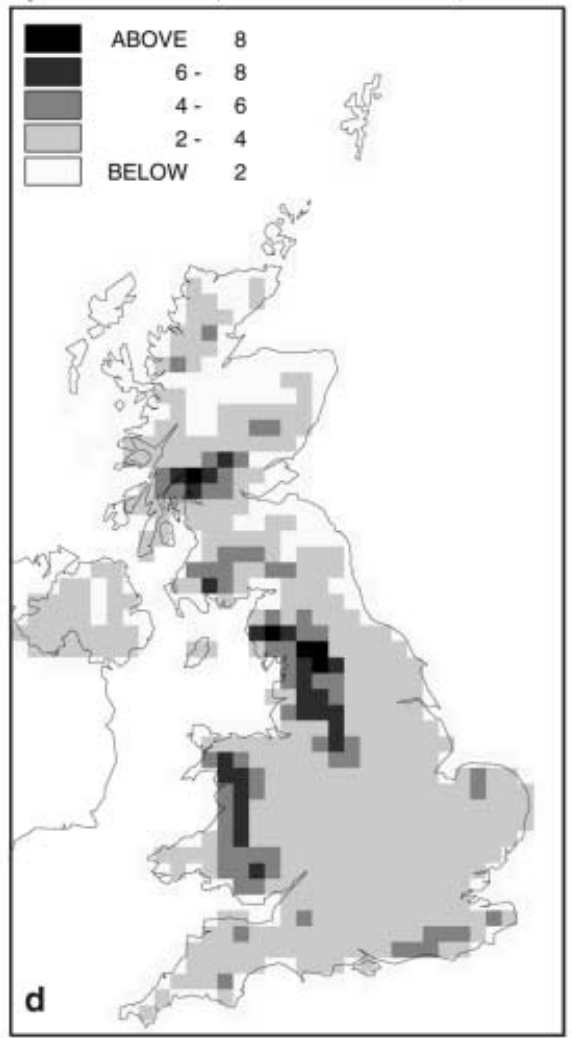

Fig. 5. a Modelled wet $\mathrm{NO}_{3}-\mathrm{N}$ $\left(\mathrm{kg} \mathrm{ha}^{-1} \mathrm{y}^{-1}\right)$, run 1 (basic model); b modelled wet $\mathrm{NO}_{3}-\mathrm{N}$ $\left(\mathrm{kg} \mathrm{ha}^{-1} \mathrm{y}^{-1}\right)$, run $2(F=3$, when rain $>1200 \mathrm{~mm} \mathrm{y}^{-1}$ ); $\mathbf{c}$ modelled wet $\mathrm{NO}_{3}-\mathrm{N}\left(\mathrm{kg} \mathrm{ha}^{-1} \mathrm{y}^{-1}\right)$, run 3 (directional rain, no enhancement); d modelled wet $\mathrm{NO}_{3}-\mathrm{N}$ $\left(\mathrm{kg} \mathrm{ha}^{-1} \mathrm{y}^{-1}\right)$, run 4 (directional rain, enhancement $F=3$, sectors 6-11) 


\section{Enhanced wet nss $\mathrm{SO}_{4}$-S deposition $\left(\mathrm{kg} \mathrm{ha}^{-1} \mathrm{yr}^{-1}\right)$}

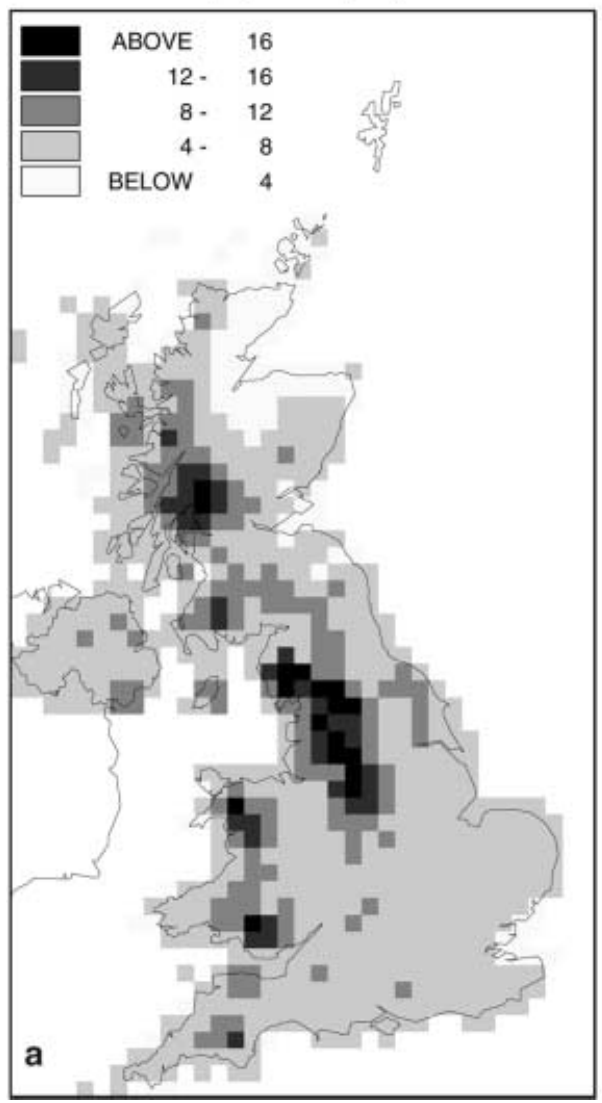

\section{Enhanced wet $\mathrm{NO}_{3}-\mathrm{N}$ deposition} (kg ha- $\mathrm{yr}^{-1}$ )

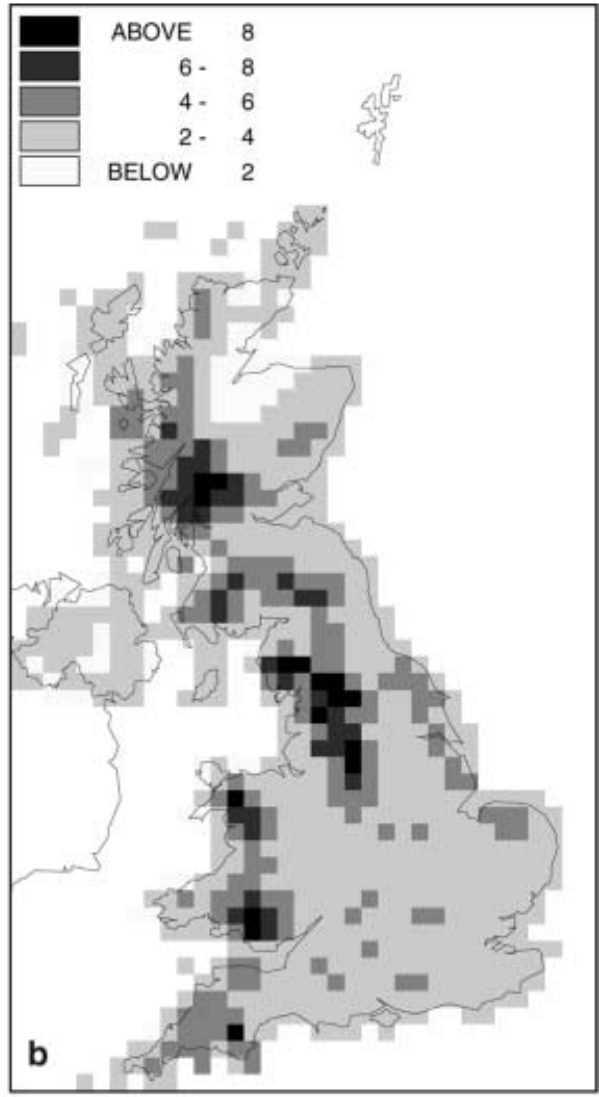

Fig. 6. a Enhanced wet nss $\mathrm{SO}_{4}-\mathrm{S}$ deposition $\left(\mathrm{kg} \mathrm{ha}^{-1} \mathrm{y}^{-1}\right)(\mathrm{RGAR}$, 1997); b enhanced wet $\mathrm{NO}_{3}-\mathrm{N}$ deposition $\left(\mathrm{kg} \mathrm{ha}^{-1} \mathrm{y}^{-1}\right)($ RGAR, 1997)

Table 5. Modelled country deposition budgets of oxidised $\mathrm{S}$ and $\mathrm{N}$ and reduced $\mathrm{N}$ for different model conditions $\left(\mathrm{ktonnes} S / \mathrm{N} \mathrm{y}^{-1}\right.$ )

\begin{tabular}{|c|c|c|c|c|c|c|c|c|c|}
\hline Species conditions & $\begin{array}{l}\text { Run } 5 \\
\text { enhanced } \\
\text { in all } \\
\text { sectors, } \\
F=3\end{array}$ & $\begin{array}{l}\text { Run } 6 \\
\text { enhanced } \\
\text { in sectors } \\
7-10 \text {, } \\
F=3\end{array}$ & $\begin{array}{l}\text { Run } 7 \\
\text { enhanced } \\
\text { in sectors } \\
6-11 \text {, } \\
F=3\end{array}$ & $\begin{array}{l}\text { Run } 8 \\
\text { enhanced } \\
\text { in sectors } \\
6-12 \text {, } \\
F=3\end{array}$ & $\begin{array}{l}\text { Run } 9 \\
\text { enhanced } \\
\text { in sectors } \\
6-12 \text {, } \\
F=2\end{array}$ & $\begin{array}{l}\text { Run } 10 \\
\text { enhanced } \\
\text { in sectors } \\
6-12 \text {, } \\
F=4\end{array}$ & $\begin{array}{l}\text { Run } 11 \\
\text { enhanced } \\
\text { in sectors } \\
6-12, \\
F=5\end{array}$ & $\begin{array}{l}\text { Run } 12 \\
\text { enhanced } \\
\text { in sectors } \\
6-12 \text {, } \\
F=6\end{array}$ & $\begin{array}{l}\text { RGAR } \\
92-94 \\
\text { deposition } \\
\text { budgets }\end{array}$ \\
\hline Dry $\mathrm{N}^{\mathrm{a}}$ (oxidised) & 52 & 52 & 52 & 52 & 53 & 52 & 52 & 52 & 40 \\
\hline Wet N (oxidised) & 87 & 77 & 79 & 79 & 77 & 81 & 83 & 84 & 110 \\
\hline Total N (oxidised) & 139 & 129 & 131 & 131 & 130 & 133 & 135 & 136 & 150 \\
\hline Total S (oxidised) & 309 & 290 & 293 & 294 & 292 & 297 & 299 & 301 & 350 \\
\hline Dry N (reduced) & 92 & 93 & 93 & 93 & 93 & 93 & 93 & 93 & 110 \\
\hline Wet N (reduced) & 95 & 87 & 88 & 89 & 87 & 90 & 91 & 92 & 120 \\
\hline Total N (reduced) & 187 & 180 & 181 & 182 & 180 & 183 & 184 & 185 & 230 \\
\hline
\end{tabular}

${ }^{\text {a }}$ Dry $\mathrm{N}$ specified in model runs includes dry deposition of all $\mathrm{NO}_{\mathrm{y}}$ species calculated in the model, i.e. $\mathrm{NO}_{2}, \mathrm{HNO}_{3}, \mathrm{PAN}, \mathrm{HONO}$, and aerosol nitrate. However, RGAR (1997) dry $\mathrm{N}$ budget is $\mathrm{NO}_{2}$ only

for oxidised $\mathrm{N}$ deposition. The sites are labelled with the codes used in the original data reports (e.g. Vincent et al., 1996). For $\mathrm{S}$ deposition, it is clear that there is little difference in the model's predictive performance between different constraints of directional dependence of seederfeeder enhancement (Fig. 7a-c). However, when seederfeeder enhancement is allowed to occur in all sectors, the $R^{2}$ value is smaller, with much more scatter in the data (Fig. 7d). The sites that suffer from over-prediction in this comparison of enhanced measurements with $F$ applied to all sectors (Fig. 7d) include Beddgelert (5119), Llyn Brianne (5124) and Pumlumon (5150). When seeder-feeder enhancement is constrained to sectors 6-12, the model under-predicts deposition at sites that are generally high elevation, high rainfall areas of Scotland or southeast England. For wet $\mathrm{N}$ deposition, the features of these comparisons (Fig. 8a-d) are very similar; the $R^{2}$ value is smaller when seeder-feeder 


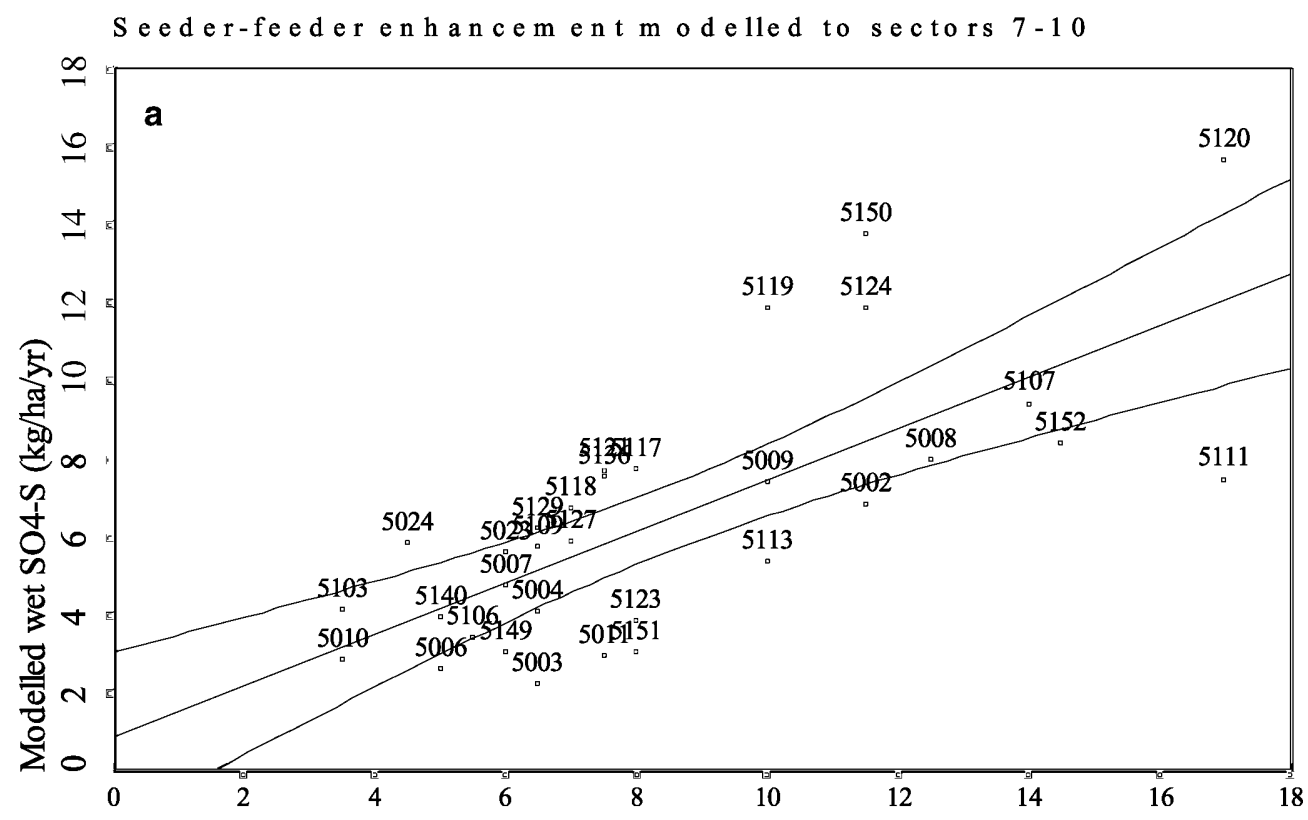

Enhanced measurements of nss SO4-S (kg/ha/yr)

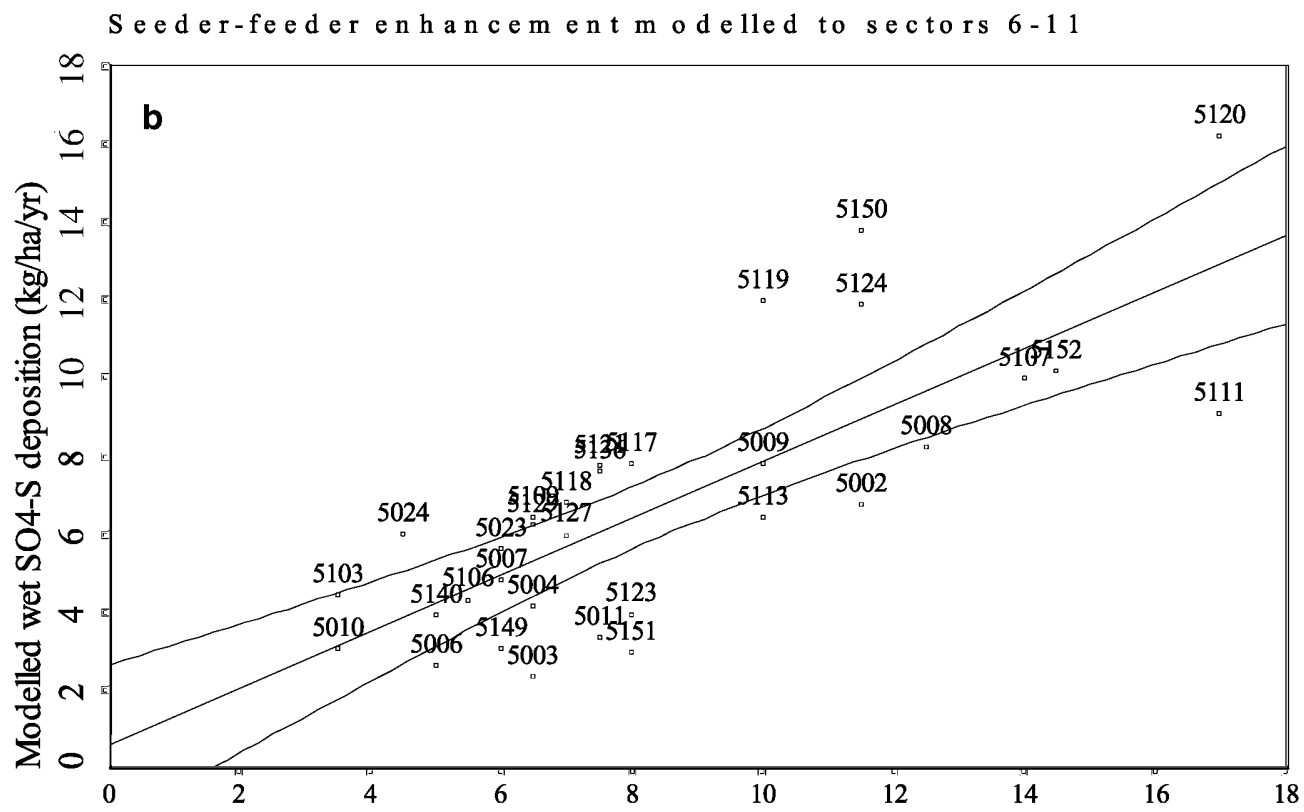

Enhanced measurements of nss SO4-S (kg/ha/yr)

Fig. 7a, b.

enhancement is unconstrained by direction, with more scatter in the data. The constrained directional seederfeeder enhancement generally under-predicts but shows less scatter. The sites that show the most under-prediction are generally sites more remote from sources.

\subsection{Sensitivity of wet deposition to seeder-feeder enhancement}

The basis of the factor $F$, of 3, for seeder-feeder enhancement is rather weak, as only few data are available for its derivation. Thus, it is important to understand the model's sensitivity to variation in $F$. The effect of varying $F$ from 2 to 6 was investigated; for these runs the sectors in which enhancement was applied was the same, i.e. sectors 6-12 but for factors of $F$ of 2, 4, 5, and 6 (runs 9, 10, 11 and 12 , respectively). The UK country deposition budgets are given in Table 5. Increasing $F$ from 2 to 6 results in an increase in modelled UK wet deposition budgets of oxidised $\mathrm{N}$ and $\mathrm{S}$ of $9 \%$ and $6 \%$, respectively. On this basis, it is clear that the sensitivity to variation in $F$ is not great, such that using a value of 3 rather than, for example 6 is not introducing large uncertainties. 


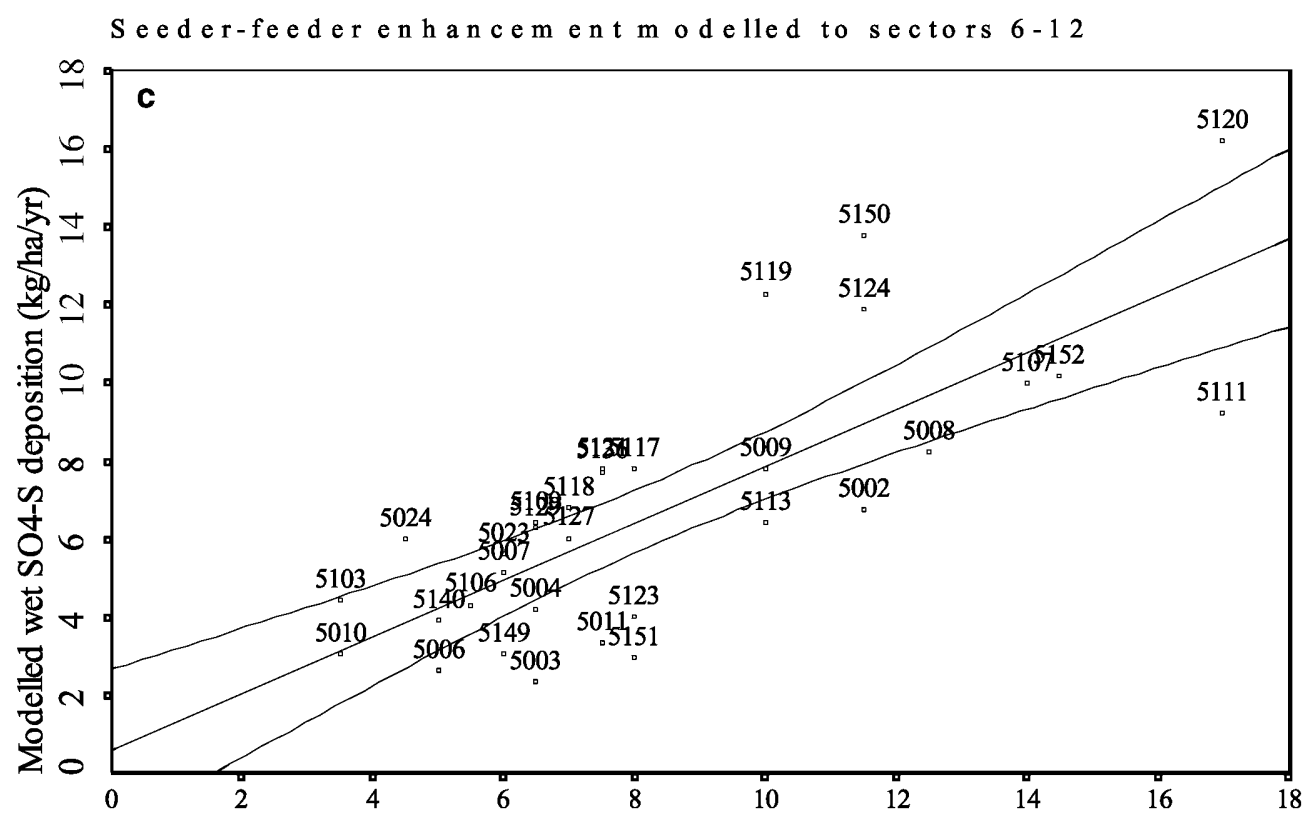

Enhanced measurements of nss SO $4-\mathrm{S}(\mathrm{kg} / \mathrm{ha} / \mathrm{yr})$

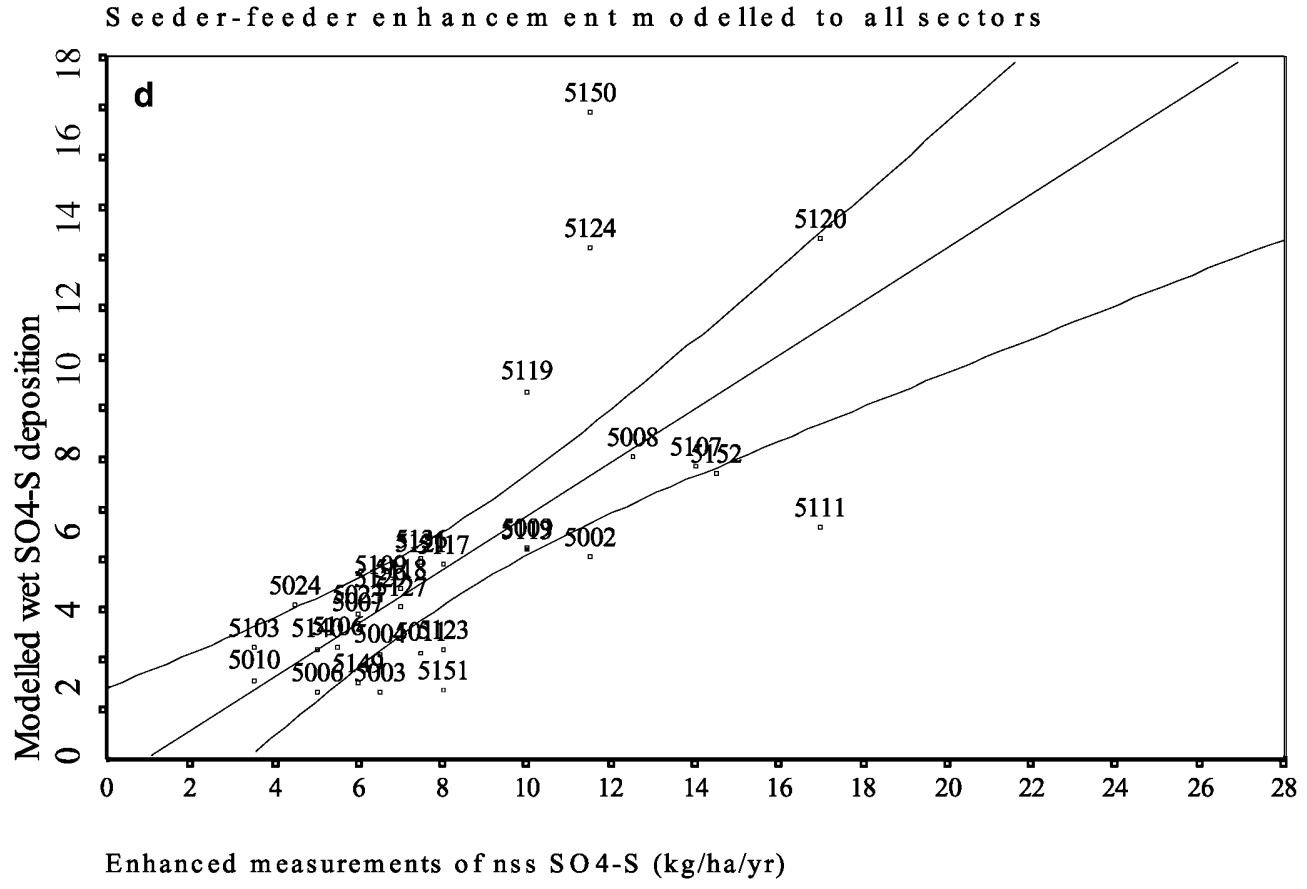

Fig. 7. a Comparison of modelled wet nss $\mathrm{SO}_{4}-\mathrm{S}$ deposition with enhanced measurement data from site grid squares, seederfeeder enhancement modelled to sectors 7-10 (data from RGAR, 1997 kindly provided by Prof. Fowler, CEH); $\mathbf{b}$ as a but for sectors $6-11$; $\mathbf{c}$ as a but for sectors $6-12$; $\mathbf{d}$ as a but for all sectors

\section{Discussion}

\subsection{The revised formulation of orographic enhancement}

In the parametrisation of the model, it is important to understand the origin and meaning of the value used for the factor $F$, the multiplier on the scavenging coefficient arising from the product of feeder precipitation, and air concentrations of inorganic aerosol species. The value of 3 for $F$ is derived from event observations given in Table 1 of seeder precipitation concentrations and seeder + feeder concentrations (i.e. measurements of hill top precipitation composition) and the relative enhancement of precipitation amounts. From these values, it is possible to infer the overall enhancement of cloud-water concentrations of species to seeder precipitation concentrations. Such enhancement factors have been measured directly (e.g. Fowler et al., 1988; Dore et al., 1990; RGAR, 1990) but these cannot be used as a reliable basis for deriving $F$ in the model because the concentration of species in cloudwater depends upon the point at which it was measured and the relative collection efficiency of the cloud-water collection device. Cloud-water droplets 
Seeder-feederenhancement modelled to sectors 7-10

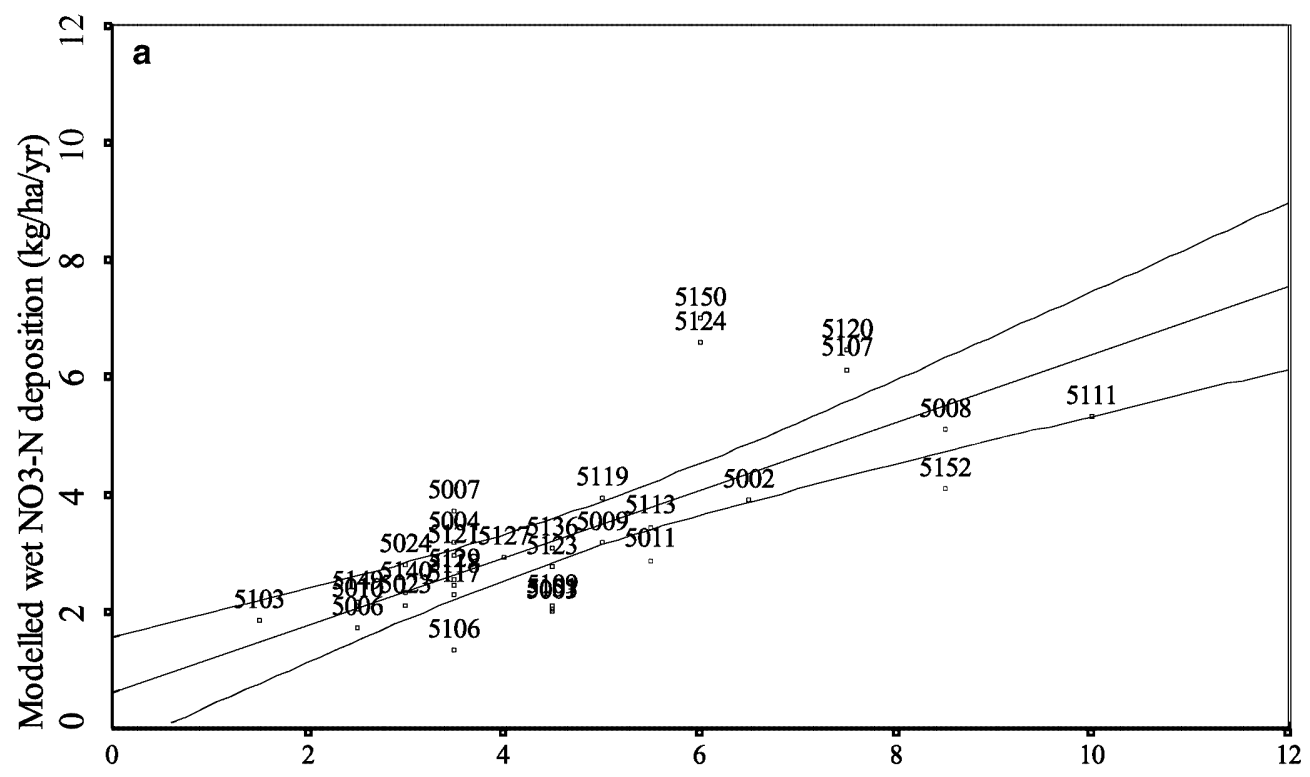

Enhanced measurements of NO3-N (kg/ha/yr)

Seeder-feederenhancement modelled to sectors 6-11

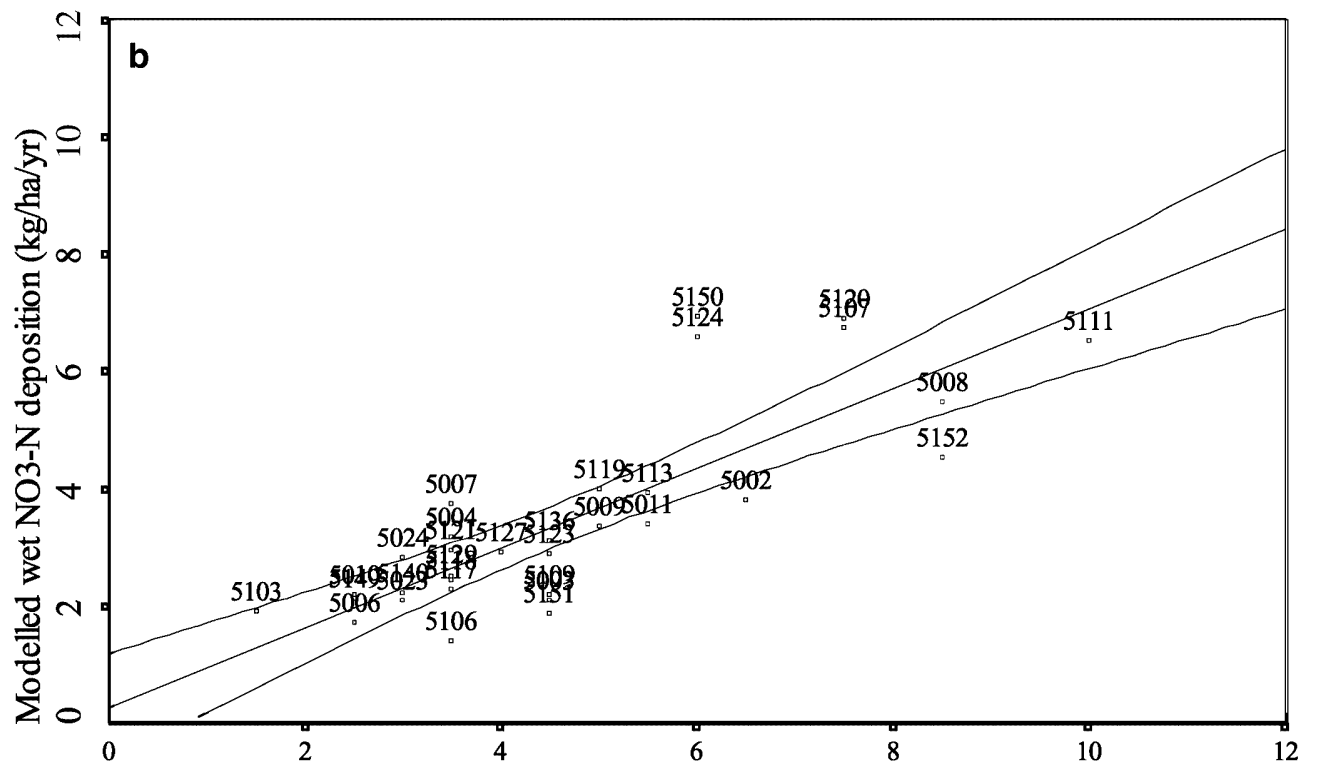

Enhanced measurements of NO3-N (kg/ha/yr)

Fig. 8a, b.

from activated aerosol particles grow in size during their transit over a hill, such that the concentrations dilute (Fowler et al., 1988) and then may increase again as the droplets evaporate. In addition, cloudwater collectors (e.g. passive string, actively sampled to strings, slit impactors) have different drop-size collection efficiencies (Choularton et al., 1997) such that a sampling artefact may bias the inferred enhancement. Thus, the calculation of a cloud-water concentration enhancement factor from a system that integrates these effects, i.e. bulk precipitation samplers, is more robust.
The factor $F$ used in the model is equivalent to the factor of 2 given by Dore et al. (1992a) and RGAR (1990) but the value of 3 has been derived directly from observations, rather than given as an estimation. The model has been tested to its sensitivity to various values of $F$ ranging from 2 to 6 , and is not very sensitive either on a country budget or a site basis to a change from 2 to 3 . However, it should be stressed that although the factors are directly equivalent in form, they are not equivalent in their application or outcome (in terms of deposition). In Dore et al.'s (1992a) methodology, enhancing the annual measurements by a factor of 2 for the inferred cloud- 


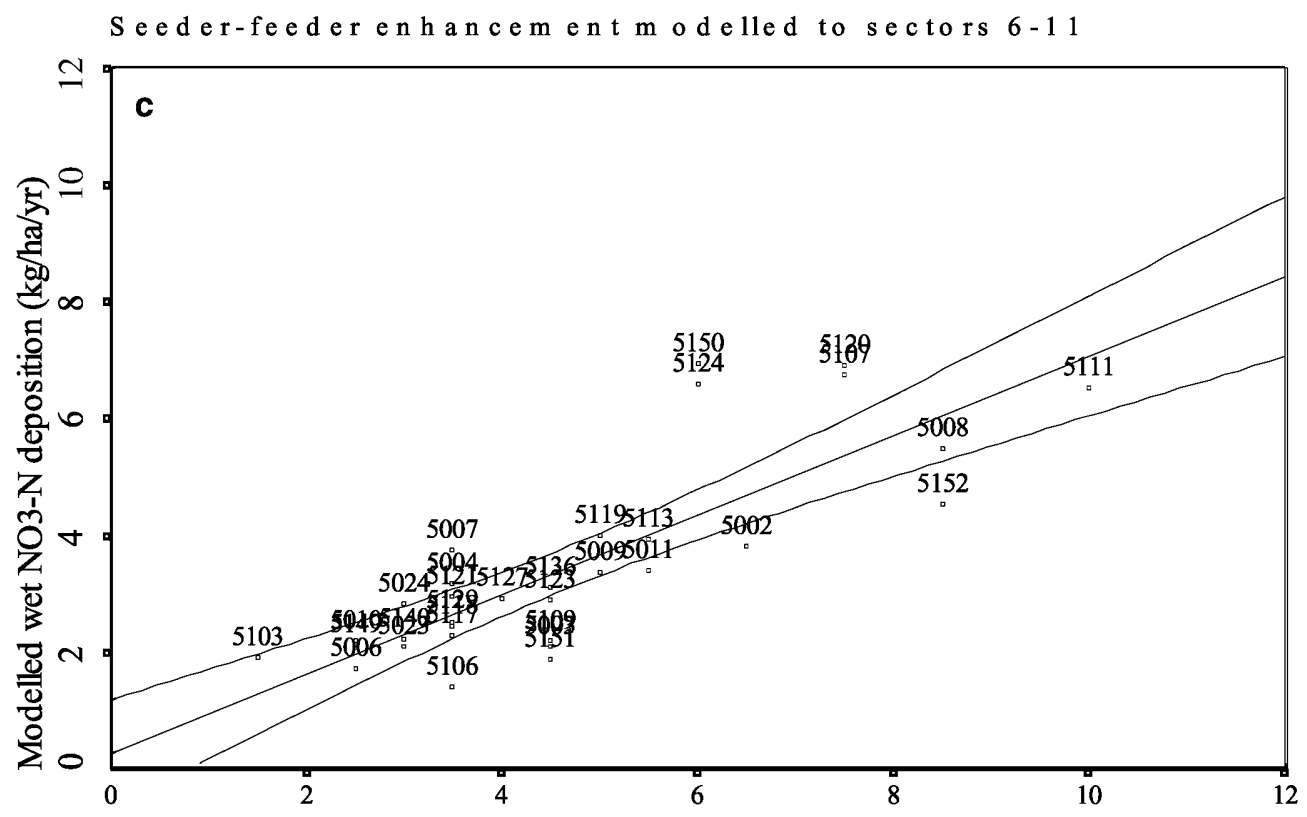

Enhanced measurements of NO3-N (kg/ha/yr)

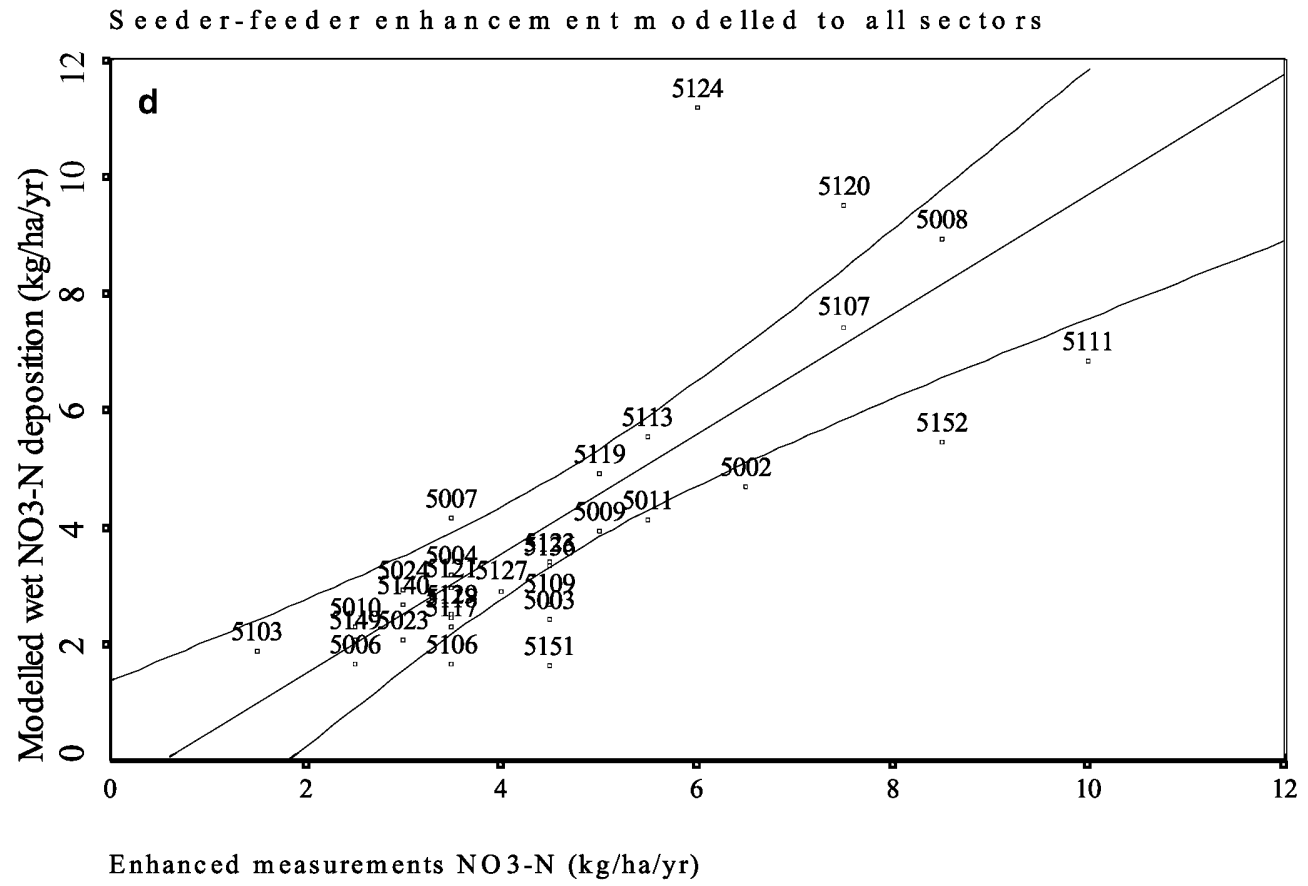

Fig. 8. a Comparison of modelled wet $\mathrm{NO}_{3}-\mathrm{N}$ deposition with enhanced measurement data from site grid squares, seeder-feeder enhancement modelled to sectors 7-10 (data from RGAR, 1997 kindly provided by Prof. Fowler, $\mathrm{CEH}$ ); $\mathbf{b}$ as a but for sectors $6-11$; c as a but for sectors $6-12$; $\mathbf{d}$ as a but for all sectors

water concentrations, integrates the enhancement of samples from all directions, whereas in the model, $F$ has been applied on a strictly directional basis.

There are a number of reasons why modelled deposition budgets of oxidised $\mathrm{N}$ and $\mathrm{S}$ may not match those given by RGAR (1997). These are considered next.

\subsection{Uncertainties}

There is some inherent uncertainty in the algorithm applied to the measurements to produce enhanced deposition fields for the UK (Dore et al., 1992a). That orographic enhancement of wet deposition from the seeder-feeder effect can occur is beyond dispute, as shown by the data summarised in Table 1 . However, the mapping procedure, by necessity, makes some assumptions. The first of these is that all precipitation in the UK in excess of a west to east coastal gradient arises from the seeder-feeder effect, and that all this arrives in westerly trajectories (Dore et al., 1992a). This is likely to be untrue as orographic enhancement of precipitation can occur by three different processes. Undoubtedly, as shown by meteorological campaign data, a very large 
proportion of this is from the seeder-feeder effect and does indeed occur in westerly frontal conditions. Unfortunately, there appear to be no long-term studies of the directional and conditional proportions of precipitation in the UK.

Further, there are some uncertainties in the enhancement factor applied by Dore et al. (1992a) who assumed that the scavenged cap-cloud-water is 2 times that of the seeding rain. Simplistically, this is directly equivalent to the factor $F$ used in the model. However, the selected value of 3 used in the model is based upon a review of the available literature for all soluble aerosol species (Tables 1 and 2). In this work, $F$ is only applied in certain directions whereas the Dore et al. (1992c) multiplication factor is effectively applied to orographic precipitation of all directional origin, the assumption being that most of this comes from frontal conditions. Dore et al.'s (1992a) factor is known to be quite variable, on an event basis and in space as depletion of the aerosol can occur along a transect (Dore et al., 1990; Fowler, 1997). The fact that the long-term monitoring data of orographic enhancement using weekly collection over a long time period (Fowler et al., 1995a; RGAR, 1997) are supportive of a factor of 2 in ion concentrations between hill rain and upwind valley rain can be interpreted in two ways. Either this indicates that the assumption that all orographic rain originates from the seeder-feeder effect in the UK is robust, or that if it is assumed that not all the orographic rain is from the seeder-feeder effect, then the mean enhancement of ion concentrations in cap-cloud on an event basis must be less than the factor of 2 assumed in the mapping.

The other major uncertainty is the way in which wet deposition is modelled. Comparing the effects of the previous parametrisation of orographic enhancement of wet deposition with that adopted here, it is evident that the old parametrisation reproduced UK deposition budgets 'better' than the new parametrisation. However, it is also clear that the old parametrisation managed to reproduce the deposition inputs of $\mathrm{S}$ and oxidised $\mathrm{N}$ to Scotland, but overestimated those to Wales and the Pennines. With the new formulation, it is clear that the model underestimates the UK country budget given by RGAR (1997) but reproduces the order of inputs of $\mathrm{S}$ and oxidised $\mathrm{N}$ well to Wales and the Pennines but seems to underestimate these to Scotland.

It is quite clear that under frontal conditions that give rise to the seeder-feeder effect, straight-line trajectories to the more remote parts of the UK are a major limiting factor. It is possible that air from emission sources in the UK may become entrained into depressions such that it is circulated back to a precipitating part of the depression, or one following in the first one's wake. Straightline trajectories will not account for such contributions to deposition at remote upland receptors in the UK. Such an observation is in keeping with the model's characteristic's that features of spatial pattern and magnitude of wet deposition are reproduced better closer to sources, than distant from them. As a result of this, it is concluded that it is better to keep the model on a strictly physical basis (i.e. the orographic parametri- sation devised here) and potentially underestimate deposition in Scotland than to employ Lee et al.'s (2000a) free parameter fit. Straight-line trajectories are now considered to be the major limitation to the model's performance.

\section{Conclusions}

The wet deposition scheme of a simple Lagrangian trajectory model has been extensively revised. A simple formulation was derived in order to model these processes. This revised formulation of wet deposition required information on the proportions of orographic and non-orographic precipitation and their directionality in any given location. Data were also required for the directionality of the seeder-feeder process.

In order incorporate this new parametrisation, it was necessary to dispense with the weighting of wet deposition by wind roses which were used formerly. Directional precipitation fields were required which were derived from both observational data and a modelling approach. Precipitation was divided into two components: orographic and non-orographic. The orographic component was derived by subtraction of the linear coast-to-coast gradient. The non-orographic component was then apportioned to directions according to meteorological data of precipitation amount by direction. The directionality of orographic precipitation was modelled.

Seeder-feeder enhancement was parametrised into the model by applying an enhancement factor on the orographic component of precipitation, based upon observations from event data. This enhancement was constrained to those directions in which it was likely that the seeder-feeder process may be in operation, based upon observational data.

The literature relating to enhanced $\mathrm{SO}_{2}$ oxidation in the presence of cap-cloud was reviewed and it was concluded that only an enhancement factor to $1.3 \% \mathrm{~h}^{-1}$ on the oxidation rate was required within the model structure.

The results from the model using the revised orographic enhancement scheme were compared with available data on estimated UK country deposition budgets of wet and dry deposited oxidised $\mathrm{N}$ and $\mathrm{S}$. The model generally under-predicts with the new parametrisation on a country scale but the pattern and magnitude of deposition is generally good in the upland high rainfall areas of Wales and England. However, in Scotland, more remote from sources, wet deposition is under-predicted in comparison to the enhanced measurements.

The sensitivity of the revised wet scavenging scheme was tested for directionality of enhancement, i.e. $F$, and its magnitude. It was found that different directional constraints on $F$ between north and south made little difference to deposition. However, when $F$ was applied to all directions, wet deposition of oxidised $\mathrm{N}$ and $\mathrm{S}$ to the UK was increased by $10 \%$. It is therefore important to apply a physically based directional constraint 
upon $F$. The uncertainties associated with the derivation of the magnitude of $F$ are large because of the paucity of data. The magnitude of $F$ was varied from 2-6 and was found to increase wet deposition of oxidised $\mathrm{N}$ and $\mathrm{S}$ to the UK by 9 and $6 \%$, respectively over this range.

It is concluded that the 'bottom-up' approach of the formulation of the wet deposition scheme is a major improvement over the former scheme, which was essentially a free parameter fit. The former scheme was devised to match the UK budgets in a top-down approach but distortion of the spatial patterns of wet deposition resulted. The uncertainties in the measurement data and the revised parametrisation of orographic enhancement were considered. The potential underestimation of the model on a UK basis, and in areas more remote from sources, balances its reliability in areas closer to sources. It was considered that this balance could not be improved upon within the constraints of using straight-line trajectories. However, the present scheme represents an effort to model all the relevant processes rather than a parameter fit.

Acknowledgements. This work was based upon a study for National Power and published with their permission. We would like to thank: Dr Ian Rodgers and Mr Alan Webb of National Power for their encouragement and enthusiasm; Dr Keith Weston of the Department of Meteorology, University of Edinburgh, for helpful discussions with the use of his orographic precipitation model; and Prof. David Fowler of the Centre for Ecology and Hydrology, Edinburgh for providing the enhanced measurement data. We would also like to thank the reviewers for their helpful and constructive comments. D.S. Lee and R.D. Kingdon were formerly at AEA Technology.

Topical Editor J.-P. Duvel thanks A.P. Barros and another referee for their help in evaluating this paper.

\section{References}

Andersson, T., Bergeron and the oreigenic (orographic) maxima of precipitation, Pageophysics, 119, 228-576, 1980/81.

Bergeron, T., Über der mechanismus der ausgiebigen Niederschläge, Ber. Deutsch. Wetter., 12, 225-232, 1950.

Bergeron, T., Operation and results of 'Project Pluvius', Am. Geophys. Union Monographs, 5, 152-157, 1960.

Bergeron, T., Preliminary results of Project Pluvius, I.A.S.H. Publications, 53, 1961.

Campbell, G. W., and D. S. Lee, Atmospheric deposition of sulfur and nitrogen species in the UK, Freshwater Biol., 36, 151-167, 1996.

Chandler, A. S., T. W. Choularton, G. J. Dollard, A. E. J. Eggleton, M. J. Gay, T. A. Hill, B. M. R. Jones, B. J. Tyler, B. J. Bandy, and S. A. Penkett, Measurements of $\mathrm{H}_{2} \mathrm{O}_{2}$ and $\mathrm{SO}_{2}$ in clouds and estimates of their reaction rate, Nature, 336, 562-565, 1998a.

Chandler, A. S., T. W. Choularton, G. J. Dollard, M. J. Gay, T. A. Hill, A. Jones, B. M. R. Jones, A. P. Morse, S. A. Penkett, and B. J. Tyler, A field study of the cloud chemistry and cloud microphysics at Great Dun Fell, Atmos. Environ., 22, 683-694, 1988b.

Choularton, T. W., and 58 others, The Great Dun Fell cloud experiment 1993: an overview, Atmos. Environ., 2393-2405, 1997.

CLAG, Critical loads of acidity in the United Kingdom, in Critical Loads Advisory Group Summary Report, Institute of Terrestrial Ecology, Edinburgh, 1994.
Derwent, R. G., Treating uncertainty in models of the atmospheric chemistry of nitrogen compounds, Atmos. Environ., 21, 14451454, 1987.

Derwent, R. G., G. J. Dollard, and S. E. Metcalfe, On the nitrogen budget for the United Kingdom and north-west Europe, $Q$. J. R. Meteorol. Soc., 114, 1127-1152, 1988.

Dollard, G. J., M. H. Unsworth, and M. J. Harvey, Pollutant transfer in upland regions by occult precipitation, Nature, 302, 241-243, 1983.

Dore, A. J., Orographic enhancement of rainfall and snowfall. $\mathrm{PhD}$ Thesis, University of Manchester, 44, 1990.

Dore, A. J., T. W. Choularton, D. Fowler, and R. Storeton-West, Field measurements of wet deposition in an extended region of complex topography, Q. J. R. Meteorol. Soc., 116, 1193-1212, 1990.

Dore, A. J., T. W. Choularton, and D. Fowler, An improved wet deposition map of the United Kingdom incorporating the seeder-feeder effect over mountainous terrain, Atmos. Environ., 26A, 1375-1381, 1992a.

Dore, A. J., T. W. Choularton, D. Fowler, and A. Crossley, Orographic enhancement of snowfall, Environ. Pollut., 75, 175179, $1992 b$.

Fowler, D., Presentation at meeting on critical loads and nitrogen, University College, London, 11th September, 1997.

Fowler, D., J. N. Cape, I. D. Leith, T. W. Choularton, M. J. Gay, and A. Jones, The influence of altitude on rainfall composition at Great Dun Fell, Atmos. Environ., 22, 1355-1362, 1988.

Fowler, D., I. D. Leith, J. Binnie, A. Crossley, D. W. F. Inglis, T. W. Choularton, M. Gay, J. W. S. Longhurst, and D. E. Conland, Orographic enhancement of wet deposition in the United Kingdom: continuous monitoring, Water, Air, Soil Pollut., 85, 2107-2112, 1995.

Gallagher, M. W., R. M. Downer, T. W. Choularton, M. J. Gay, I. Stromberg, C. S. Mill, M. Radojevic, B. J. Tyler, B. J. Bandy, S. A. Penkett, T. J. Davies, G. J. Dollard, and B. M. R. Jones, Case studies of the oxidation of sulfur dioxide in a hill capcloud using ground and aircraft based measurements, $J$. Geophys. Res., 95, 18 517-18 537, 1990.

Hill, T. A., T. W. Choularton, and S. A. Penkett, A model of sulphate production in a cap-cloud and subsequent turbulent deposition onto the hill surface, Atmos. Environ., 20, 1763-1771, 1986.

Hill, T. A., A. Jones, and T. W. Choularton, Modelling sulphate deposition onto hills by washout and turbulence, $Q$. J. R. Meteorol. Soc., 113, 1217-1236, 1987.

ISMCS, International Station Meteorological Climate Summary. Fleet Numerical Meteorology and Oceanography Detachment, National Climatic Data Center and USAFETACOL-A. CDROM distributed by the National Oceanic and Atmospheric Administration, Boulder, Colorado, 1995.

Inglis, D. W. F., T. W. Choularton, and A. J. Wicks, The effect of orography on wet deposition in an industrial area, $Q . J . R$. Meteorol. Soc., 121, 1575-1588, 1995.

Lee, D. S., R. D. Kingdon, M. E. Jenkin, and A. Webster, Modelling the contribution of different sources of sulphur to atmospheric deposition in the United Kingdom, Environ. Model. Assess., 5, 105-118, 2000a.

Lee, D. S., R. D. Kingdon, M. E. Jenkin, and J. A. Garland, Modelling the atmospheric oxidised and reduced nitrogen budgets for the UK with a Lagrangian multi-layer long-range transport model, Environ. Model. Assess., 5, 83-104, $2000 \mathrm{~b}$.

Lee, D. S., R. D. Kingdon, J. M. Pacyna, A. F. Bouwman, and I. Tegen, Modelling base cations in Europe - sources, transport and deposition of calcium, Atmos. Environ., 33, 2241-2256, 1999.

Metcalfe, S. E., J. D. Whyatt, and R. G. Derwent, A comparison of model and observed network estimates of sulfur deposition across Great Britain for 1990 and its likely source attribution, Q. J. R. Meteorol. Soc., 121, 1387-1411, 1995.

National Power, An examination of the effect of altitude on wet deposition in the Eastern Pennines, JEP 3070/014, National Power Research and Engineering, Swindon, 1994a. 
National Power, An examination of the effect of altitude on deposition in South Wales, Data report, personal communication, National Power, Swindon, 1994b.

Penkett, S. A., B. M. R. Jones, K. A. Brice, and A. E. J. Eggleton, The importance of atmospheric ozone and hydrogen peroxide in oxidising sulfur dioxide in cloud and rainwater, Atmos. Environ., 13, 123-137, 1979 .

RGAR, Acid deposition in the United Kingdom 1986-1988, Third report of the United Kingdom Review Group on Acid Rain, Warren Spring Laboratory, Stevenage, 1990.

RGAR, Acid deposition in the United Kingdom 1992-1994, Fourth report of the United Kingdom Review Group on Acid Rain, AEA Technology, Culham Laboratory, Oxfordshire, 1997.

Salway, A. G., J. W. L. Goodwin, and H. S. Eggleston, UK emissions of air pollutants 1970-1993, National Atmospheric Emissions Inventory, AEA Technology, Culham Laboratory, Oxon. UK, 1996.
Seinfeld, J. H., Atmospheric chemistry and physics of air pollution, Wiley Interscience, New York, 1986.

Smith, R. B., The influence of mountains on the atmosphere, $A d v$. Geophys., 21, 87-230, 1979.

Spiro, P. A., D. J. Jacob, and J. A. Logan, Global inventory of sulfur emissions with a $1^{\circ} \times 1^{\circ}$ resolution, J. Geophys. Res., 97, 3023-3036, 1992.

Vincent, K. J., G. W. Campbell, C. E. H. Downing, S. E. Hasler, M. Davies, J. R. Stedman, L. E. Sansom, C. Briscombe, and H. M. Page, Acid deposition in the United Kingdom: the first ten years, AEA Technology Report 20017001, Culham Laboratory, Oxfordshire, UK, 1996.

Weston, K. J., Objectively analysed cloud immersion frequencies for the United Kingdom, Meteorol. Mag., 121, 108-111, 1992.

Weston, K. J., and M. G. Roy, The directional dependence of the enhancement of rainfall over complex orography, Meteorol. Appl., 1, 267-275, 1994. 